


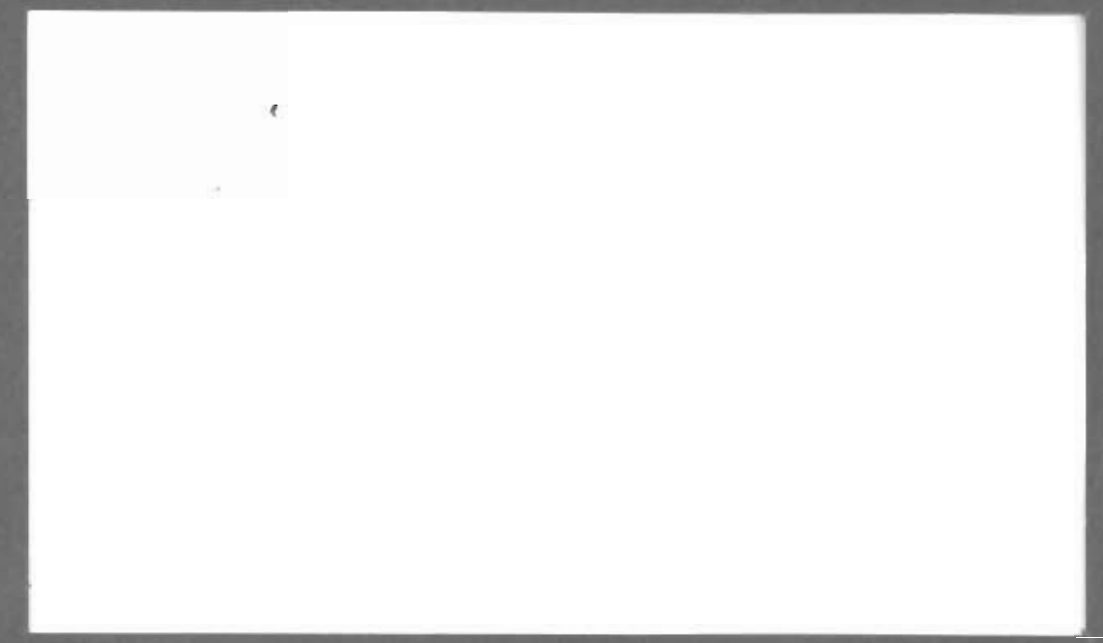

\section{L.EGAL NOTICE}

This report was prepared as an occount of Government sponsored work. Neither the United States, nor the Commission, nor any person acting on behalf of the Commission:

A. Makes any warranty or representation, expressed or implied, with respect to the accuracy, complefeness, or vsefulness of the informalion contained in this report, or that the use of any information. apparatus, method, or process disclosed in this report may not in. fringe privalely owned rightsi or

B. Assumes any liabilities with respect to the vie of, or for damages resulting from. the use of any information, apporotus, method, or process disclosed in this repart.

As used in the above, "person acting on behalf of the Commission" includes any employee or contractor of the Commission, ar employee of such confractor, to the extent that such employee or contractor of the Commission, or employee of such contractor prepares. disseminates, or provides occess 10, any information pursuant to his employment or contract with the Commission, or his employment with such coniractor.

\section{PACIFIC NORTHWEST LABORATORY RICHLAND. WASHINGTON operafed by \\ BATTELLE MEMORIAL INSTITUTE}

for the 
CONCEPTUAL FACILITY DESIGN DESCRIPTION FOR THE

SITE FACILITIES

No. 22

August 15,1968

PACIFIC NORTHWEST LABORATORY

Richland, Washington 99352

Operated by

Batte1le Memorial Institute for the

U.S. Atomic Energy Commission under Contract No. AT(45-1)-1830 
BNWL - 500

Volume 22

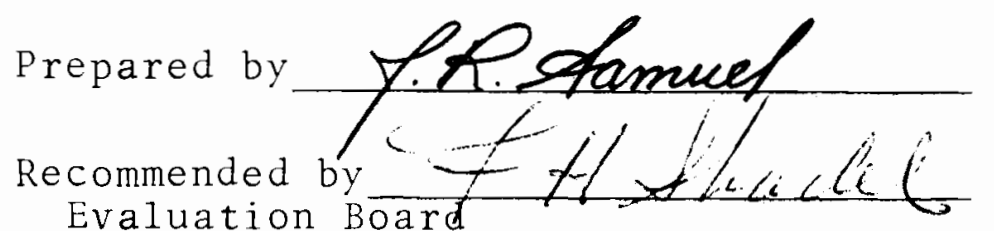

Date $11 / 27 / 67$

Date $3 / 15 / 68$

Approved by

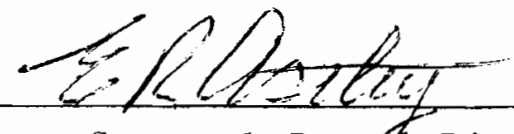

Date $3 / 22 / 68$

Configuration Control Boaf Directive: No. A-0013A

Approved by AEC Letter, J. M. Shivley, Project Administrator, FFTF Project Office, Richland Operations Office; to E. R. Astley, FFTF Project Manager, Subject," FFTF CFDD \#22 - Sites Facilities, dated August 15, 1968 . 


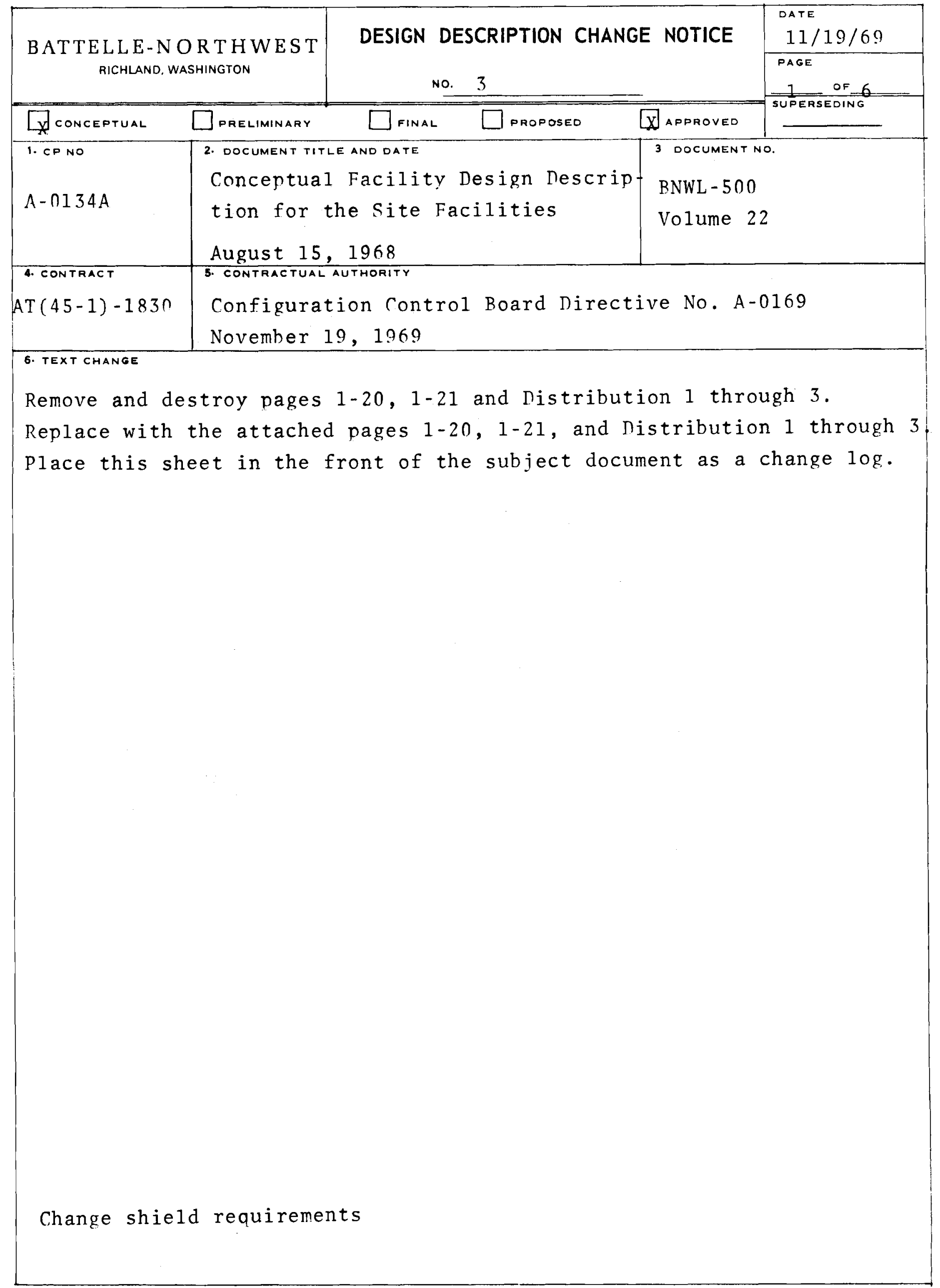




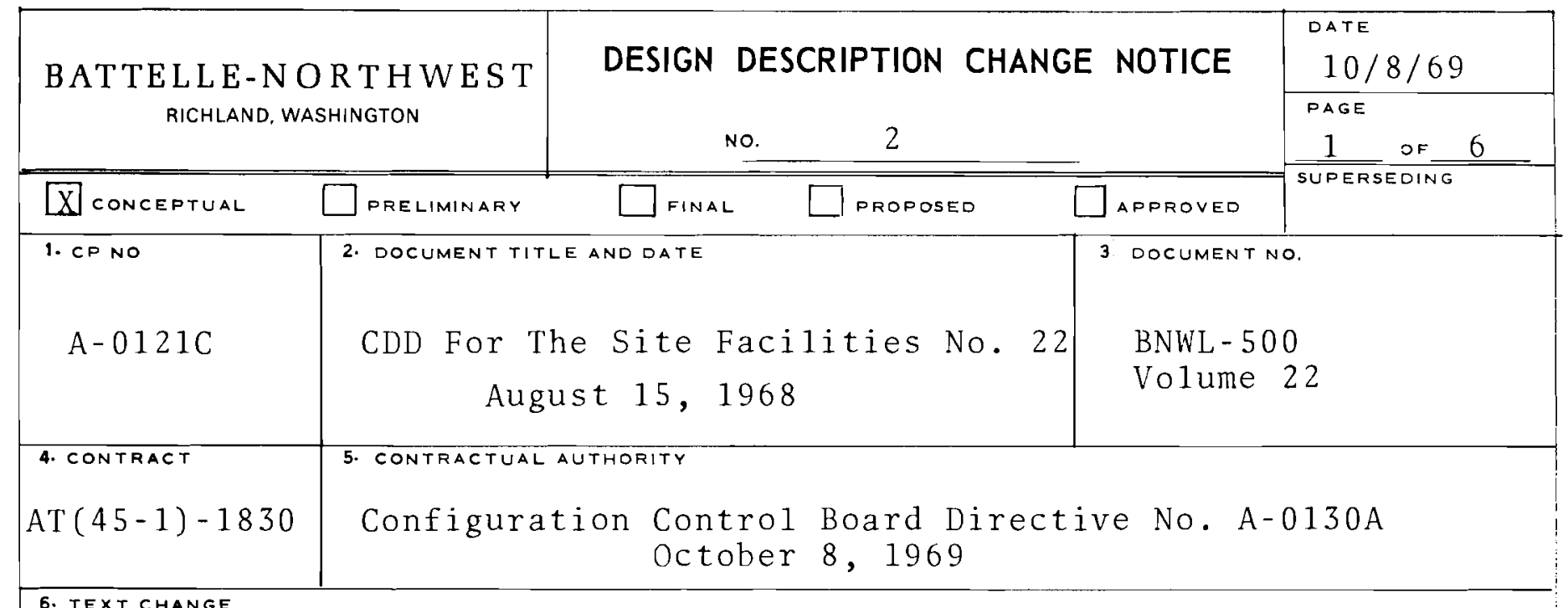

6. TEXT CHANGE

Remove and Destroy Pages 1-4, 1-17 and Distribution 1 Through 3

Add the Attached Pages 1-4, 1-17 and Distribution 1 Through 3

Place this sheet in the front of the subject document as a change $10 \mathrm{~g}$.

Redirection of conceptual design 


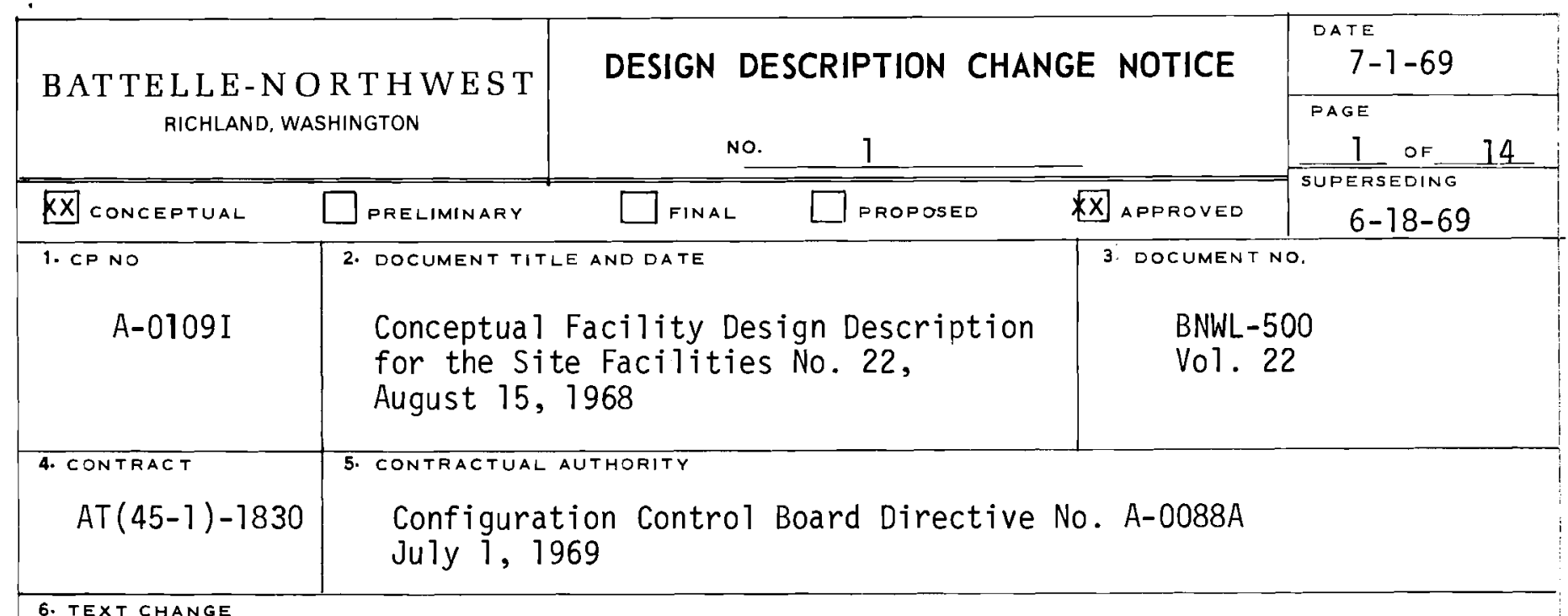

Remove and destroy pages iii, 1-5, 1-10, 1-14, 1-20, A-1, E-1, E-2 and Distribution 1 through 2.

Add the attached pages $i \mathrm{i}, 1-5,1-10,1-14,1-20,1-21, \mathrm{~A}-1$, $E-1, E-2, E-3$, and Distribution 1 through 3 .

Place this sheet in the front of the subject document as a document change log.

Incorporate Design Safety Criteria and Editorial corrections. 
BNWL - 500

Volume 22

TABLE OF CONTENTS

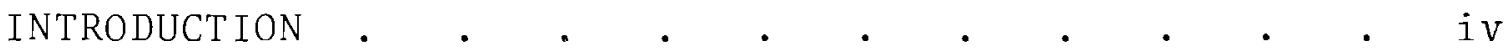

1.0 FUNCTIONS AND DESIGN REQUIREMENTS . . . . . $1-1$

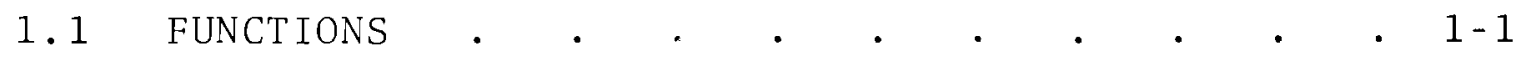

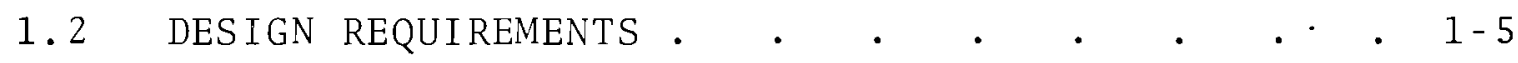

1.2.1 Basic Design Requirements . . . . . . . $1-5$

DDCN-1 1.2.2 Design Safety Criteria . . . . . . . . . $1-20$

2.0 PHYSICAL DESCRIPTION OF THE FACILITY. . . . $2-1$

2.1 SUMMARY DESCRIPTION • . . . . . . . . . $2-1$

2.2 DETAILED DESCRIPTION. . • • • • • . . $2-2$

2.2.1 Ground Improvements and Civil Engineering Features. . . . . . . . . 2-2

2.2.2 Utility Services. . . . . . . . . . . . $2-7$

2.2.3 Auxiliary Structures. . . . . . . . . . . 2-10

3.0 SAFETY CONSIDERATIONS . • . . . . . . . $3-1$

3.1 HAZARDS . . . . . . . . . . . $3-1$

3.2 PRECAUTIONS .

4.0 PRINCIPLES OF OPERATION • • • • • • • • • $\quad$ • $4-1$

5.0 MAINTENANCE PRINCIPLES . • . . . . . . $5-1$

5.1 GENERAL MAINTENANCE . . . . . . . . . $5-1$

5.2 PREVENTIVE MAINTENANCE . . . . . . . . . $5-1$

Appendix A - References . . . . . . . . . A-1

Appendix B - Support Information Requirements . . . B-1

Appendix C - Interfaces . . . . . . . . $\mathrm{C}-1$

Appendix D - Systems Requiring Utilities Service • . D-1

Appendix E - FFTF Site Facility Codes,

Appendix F - Systems Requiring Space With Site
Facility . $. \quad . \quad . \quad . \quad . \quad$. .1

Appendix G - Drawings . . . . . . . . . . . G-1 
BNWL -500

Volume 22

\section{SITE FACILITIES}

INTRODUCTION

'This Conceptual Facility Design Description covers the site facilities which are classified in the three following general catagories:

- Grounc improvements and Civil Engineering features

- Plant utility services

- Auxiliary structures exclusive of, and outside the reactor building complex, heat transport system building, and the containment structure.

This CFDD describes all the FFTF utility services except electrical, which is covered in the Primary Electrical Power System and the Building Electrical Power System. The functions and design requirements included in Section 1.0 are baseline. The remaining sections are nonbaseline and discuss conceptual design features which have a high confidence level for meeting the FFTF objectives.

The contents of this document support and expand the requirements established in the Overall Conceptual Systems Design Description. 1

1 Refer to References, Appendix A, Item 1. 
BNWL - 500

Volume 22

SECTION 1.0 FUNCTIONS AND DESIGN REQUIREMENTS

\subsection{FUNCTIONS}

The primary functions of the FFTF site Facility covered by this conceptual design description are:

- Provide the necessary ground improvements and Civil

Engineering features

- Provide the necessary plant utilities except electrical power and communication services ${ }^{1}$

- Provide necessary structures and auxiliary facilities, exclusive of, and outside the reactor building complex, heat transport systems building, and the containment structure.

A. The functions of the ground improvements and Civil Engineering features are as follows.

1. Provide industrial security for the FFTF.

2. Provide the necessary real estate, vehicular and personnel access features, ${ }^{2}$ and building arrangements for safe and efficient operation and maintenance of the FFTF.

3. Provide for the safe disposal of noncontaminated process wastes.

4. Provide ground improvements to assure safe plant operation, future plant expansions, and process additions.

5. Provide a master plan integrating the auxiliary structures (Ref.. paragraph 1.1.C), futurc expansions (see following paragraph) and future facility requirements including the associated equiprient,

1. Refer to Interfaces, Appendix C, Items 1, 2, and 3. 2. Refer to Interfaces, Appendix C, Item 11. 
B.NHL -500

Volume 22

access space for personnel, and maintenance access as required for operations and maintenance.

6. Provide space for future expansion of FFTF facilities and systems as follows:

- Radioactive Maintenance System ${ }^{1}$

- Inert Gas Cell Examination Facility ${ }^{1}$

- Heat Dump Facilities ${ }^{1}$

- Engineering and Service Area ${ }^{2}$

- Heat Transport Systems Building ${ }^{2}$

- Filter Building

7. Provide for the routing of all service lines. These include:

- Electrical power distribution

- Lighting (outside)

- Communication 1 ines

- Sanitary water lines

- Process water 1 ines

- Sanitary sewer 1 ines

- Process sewer lines

- Nitrogen 1 ines

- Argon lines

- Sodium receiving lines

- Sodium disposal 1 ines

- Radioactive liquid waste lines

- Compressed air lines

- Steam lines

B. The functions of the plant utility service are as follows:

1. Provide the sanitary and process water supply system. 3

1. Refer to Interfaces, Appendix C, Items 12, $15, \varepsilon 16$.

2. Refer to Interfaces, Appendix C, Item 5 .

3. Refer to Support Information Requirements, Appendix $B$, I tem 1 . 
BNWL- 500

Volume 22

2. Provide the sanitary sewer collection and disposal system。

3. Provide the process sewer collection and disposal system.

4. Provide the piping system for the transfer of radioactive liquid waste between facilities.

5. Provide service lines for heating and process cleaning。 1

C. The functions of the auxiliary structures are as follows :

1. Provide shelter, space, and structural features to house facilities in support of this CFDD. This includes the associated allied equipment, access space for personnel, and the maintenance as required for operations and maintenance. These facilities are:

- Exhaust Stack

- Maintenance and Materials Storage Warehouse

- Steam Plant (Heating \& Cooling Facilities)

- Fuel Storage (for Heating and Emergency Power)

- Water Supply System

- Sewage Disposal Facility

- Miscellaneous Structures

- Gas Bottle Storage Facility

2. Provide shelter space and structural features to house facilities in support of other facilities and systems. This includes architectural and

1. Refer to Support Information Requirements, Appendix B, I tem 2 . 
BNWL -500

Volume 22

structural features, embedded items, embedded interface items, and maintenance and personnel access.

These are as follows:

- Exhaust Filters 1

- Exhaust Fans ${ }^{1}$

- Reactor Heat Dump ${ }^{2}$

- Closed Loops Heat Dump 3

- Emergency Core Cooling Heat Dump ${ }^{4}$

- Stack Monitoring Building

- Sodium Disposal Facility 5

DDCN - 2

- Radioactive Liquid Waste Loadout Station ${ }^{6}$

- Electrical Substations and Switchgear Buildings ${ }^{7}$

- Emergency Power Generation Station ${ }^{7}$

- Sodium Receiving Station ${ }^{5}$

- Inert Gas Receiving Station ${ }^{8}$

This CFDD will provide shelter, space and/or structural support for all the facilities listed in paragraphs C.1 and C.2, but will interface with the reference systems for the complete concept.

3. Provide biological shielding for structures and areas containing radioactivity so that personnel exposure does not exceed code limits.

4. Provide for decontamination of structures where radioactive materials are handled or stored.

\footnotetext{
1. Refer to Interfaces, Appendix C, Item 8.

2. Refer to Interfaces, Appendix C, Item 13.

3. Refer to Interfaces, Appendix C, Item 15.

4. Refer to Interfaces, Appendix C, Item 14.

5. Refer to Interfaces, Appendix C, Item 17.

6. Refer to Interfaces, Appendix C, Item 7 .

7. Refer to Interfaces, Appendix C, Item 2 .

8. Refer to Interfaces, Appendix C, Item 18.
} 
BNWL -500

Volume 22

\subsection{DES IGN REQUIREMENTS}

The following baseline design requirements are necessary to perform the functions as defined in section 1.1 .

1.2.1 Basic Design Requirements

A. The design of the Site Facility shall be performed in accordance with the building codes, standards, guides, specifications, and Design Criteria compiled in

DDCN-1 Appendix E. The latest edition of each shall be used.

- The Uniform Building Code of the Pacific Coast

Building Conference, 1967 Edition, shall be used as the basic design code.

- The Hanford Engineering Standards shall be used

DDCN-1 where applicable.

B. Detailed criteria and responsibilities for determining and verifying the quality of the Site Facility shall be defined for the following areas:

- Design adequacy

- Fabrication and construction quality

- operational capability

C. The Site Facility shall be designed for a reliability and maintainability consistent with achieving an FFTF overall plant availability of $75 \% .^{1}$ Consideration shall be given to the effects of this facility on the availability of interfacing systems.

1. Refer to Support Information Requirements, Appendix B, Item 6 . 
BNWL $\cdots 500$

Volume 22

D. Ground improvements and Civil Engineering features shail be designed to meet the following requirements:

1. The Site Facility design shall provide a set of master plans integrating the temporary construc. tion requirements, and construction layout, with the permanent facilities. These plans shall show as a minimum, buried lines, all permanent structures, temporary construction, roads, railroads, future building expansions, and future proposed structures.

2. An eight foot high fence shall be provided for industrial security. The fence shall be in com. pliance with $\mathrm{HW}-4680 \cdot \mathrm{S}^{1}$ and $\mathrm{AC}-5 \cdot 20^{1}$. The main entrance to the plant shall not be within the boundaries of the perimenter fence, however, the remainder of the site facilities shall be inside the security area. A minimum number of gates shall be used. The gates shall be equipped with chain and padlock. The padlock shall be in compliance with the Hanford Security System.

3. The Site Facility design shall provide the necessary real estate ${ }^{2}$ and plant arrangement to assure safe and efficient operations and maintenance of the FFTF。 The design and overall arrangement shall incorporate provisions for emergency evacuation of all personnel.

4. A 20 foot wide paved access and perimeter road sys tem shall be designed to service the FFTF Site Facilities. The main access to the FFTF Site shall

1. Refer to Codes, Standards, and Criteria, Appendix E, Item 11 。

2. Refer to References, Appendix A, I tem 3. 
BNWL -500

Volume 22

be from the Hanford Project Highway System.1 Service roads from the perimeter road to the various site facilities shall be provided as required。 ${ }^{2}$ These roads shall be designed in accordance with AC-6 and HWS-6131 through HWS $61360^{3}$ The main access road and the perimeter road shall have a painted centerline strip conforming to the requirements of Department of Highways, State of Washington, "Standard Specification。"

5. A railroad spur shall be designed connecting the Site to the Hanford Project Railroad System. ${ }^{1}$ Rail access shall be provided to those facilities within the Site requiring railroad service。 ${ }^{1}$ Railroads shall be in accordance with AC-7 and HWS-5722-S. ${ }^{3}$ The main railroad spur from the Hanford main line shall be designed to permit construction materials to be brought to the site.

6. Unrestricted access shall be provided in a specified area ${ }^{4}$ at the containment vessel boundary in case it it necessary to change the reactor internals after plant startup。

7. The Site Facility arrangement shall be designed to provide space for future expansion of the Filter Building, Inert Gas Cell Examination Facility, Radioactive Maintenance Ce11, FFTF Engineering Operations Building, and the electrical substations.

1. Refer to Interfaces, Appendix C, Item 21 。

2. Refer to Systems Requiring Utilities Service, Appendix D。

3. Refer to Codes, Standards, and Criteria, Appendix E, Item 11 。

4. Refer to Interfaces, Appendix C, Items 5 and 10。 $1-7$ 
BNIL -500

Volume 22

The mininum space provided for future expansions of these facilities shall be at least equal to the original area provided for the facility.

8. The Site Facility design shall provide paved parking space as necessary for operations, maintenance, and service vehicles and equipment. These parking areas shall be located at service entrances, end of access roads, and at other areas requiring frequent access.

9. The Site facility shall provide a paved parking area for employees. Initial design shall provide for 100 vehicles in the employee parking areas with expansion capability to increase the area to 200 vehicles. A separate paved parking space located adjacent to the FFTF Engineering Operations Building shall be designed to accommodate 20 vehicles. All parking spaces shall have stall markings painted on the paved surface and precast concrete bumper logs installed.

10. A separate area shall be designed to accommodate the loading and unloading of buses. This area should accommodate buses carrying commuting employees and visiting personnel.

11. Signs shall be provided to direct traffic, give directions, and warn personnel of hazards. Signs shall be in accordance with $\mathrm{AC}-3, \mathrm{AC}-5$, or $\mathrm{AC}-7,1$ and to the "Standard Specifications" Department of Highways, State of Washington.

1. Refer to Codes, Standards, and Criteria, Appendix E, Item 11 . 
$\mathrm{BNWL}-500$

Volume 22

12. The Site Facility design shall provide for surface drainage and landscape features. All areas except those which are to be landscaped shall be surfaced with a 4 inch leveling course of predominantly coarse gravel to retard wind erosion. The surfacing shall be formed by depositing pit run gravel to obtain the desired surface and to leave the area free of stones larger than 3 inches in the greatest dimension. All borrow pits, spoil, excavation, and backfill areas shall also be stabilized.

The landscaped area shall be designed to give an appealing appearance to the main FFTF entrance。 This work will include trees, grass, shrubs, and lighting effect. All plant material shall conform to standard Grading Codes for Nursery Stock and shall be No。 1 grade。 Plants shall be hearty stock grown under climatic conditions similar to those at the FFTF site and shall be of the type not normally subject to local disease and insects. An automatic sprinkler system shall be designed and installed as part of the landscaping work. All electrical wiring, including connections to remote control valves, shall be performed in accordance with the National Electrical Code, Standard for Electric Wiring and Apparatus.

13. A pond shall be designed to dispose of the process liquid waste collected by the process sewer system. ${ }^{1}$ The size and location of the pond is dependent on the final site location, ground water table characteristics, and soil percolation rates. The design 
BNWL - 500

Volume 22

shall be based on field tests or known geological features once the site has been selected. ${ }^{1}$

DDCN-1 14. Deleted

E. The following design requirements are necessary to perform the functions for the FFTF utility services, except for electrical and communications:

1. The Site Facility design shall provide sanitary and process water requirements for the FFTF. ${ }^{2}$ The sanitary water distribution system shall be a loop system to serve Fire protection needs and to assure a reliable and economic water supply from two directions to each important demand point. Valves shall be installed in the system in such a manner to permit maintenance with the minimum interruption of service. Sizes of the mains are dependent upon sanitary, process, and fire demand usage. ${ }^{3}$ Water lines shall not be located under buildings or roads (except at road crossings), or other facilities. Road crossing shall be held to a minimum. Fire hydrants shall be spaced and located in

1. Refer to References, Appendix A, Item 3.

2. Refer to Support Information Requirements, Appendix B, I tem 1 .

3. Refer to Interfaces, Appendix C, Item 9. 
BNWL - 500

Volume 22

accordance with the National Fire Codes. ${ }^{1}$ Design shall permit early construction so that the system will serve the facility during construction.

2. All utility lines shall be buried, where practical. Utility service shall be provided to those facilities listed in Appendix D. Consideration shall be given for unusual traffic over buried lines. The minimum allowable design traffic loads are tabulated in DG-502-AC. ${ }^{2}$

3. The Site Facility design shall provide complete sanitary sewer system for the FFTF. This includes the sanitary sewer lines and the sewage disposal facility. Design shall permit early construction of this service so that it may be used during construction stages of the FFTF.

4. All piping materials shall be compatible with the materials which they are designed to carry and shall be selected for a minimum 20 year service life.

5. The Site Facility shall include process sewer system design in accordance with applicable standards, guides, specifications, and criteria previously specified herein.

6. The process sewer system shall be designed to include sampling (dip) and monitoring (remote) of the activity levels. Instruments and controls shall be provided to sound an alarm in the control room

1. Refer to Codes, Standards and Criteria, Appendix E, I tem 23.

2. Refer to Codes, Standards and Criteria, Appendix E, I tem 15 . 
BNWL - 500

Volume 22

and valving shall be provided to shut off the flow when radioactivity levels exceed allowable limits of disposal to ground. The system discharging to the process sewer system shall be designed to include the required valving and alarms ${ }^{1}$ necessary to accomplish this if the potential for inadvertent radioactivity release exist.

7. Radioactive and potentially radioactive lines shall have sufficient ground cover (or other shielding media) so that the requirements of AECM-0524 will be met. Shielding will be designed for the highest level of radioactivity that the line will carry.

8. The Site Facility design shall provide the FFTF steam heating plant and distribution system. 2

Steam must be supplied to the Service Piping system ${ }^{3}$ for decontamination, cleaning, and other services within the reactor building complex as well as the requirements for the Site Facility.

9. Piping shall be based on the applicable codes and specifications found in Appendix E, Items 3, 4, 5, $8,12,14,15,18$, and 25 .

10. All other utility lines, including electrical and communications, shall be routed in the most direct and practical manner. Utilities handling nonradioactive services shall be routed away from radioactive sources. Utility lines shall be located in

1. Refer to Interfaces, Appendix C, Items 19 and 20.

2. Refer to Support Information Requirements, Appendix B, Item 2 .

3. Refer to Interfaces, Appendix C, Item 6. 
BNWL - 500

Volume 22

one excavation, where practical, but they shall be sufficiently spaced to allow individual line maintenance without disturbing other services nearby. Utilities carrying redundant services (such as electrical lines) shall be routed in separate excavations or trenches to preclude interferances.

11. The process waste disposal system shall conform to the requirements stipulated in AEC Manual RL 0510 "Waste Disposal".

12. The Site Facility design shall route the inert gas lines from the gas storage facilities to the various buildings requiring service in the most direct manner. These lines shall be buried.

Structural supports will be provided for overhead lines. Piping shall be in compliance with DG-100-M. ${ }^{1}$

13. The Site Facility design shall make provisions for installation of sodium lines from the sodium receiving station ${ }^{2}$ to the sodium storage area ${ }^{3}$ and from the reactor building to the sodium disposal facility. The design of such lines include shielding, support, expansion, and heating of the lines. The piping, valves, and fittings shall be compatible with those selected for the Sodium Receiving and Processing System. ${ }^{2}$ Lines shall be installed below grade whenever feasible.

F. The following design requirements are necessary to perform the functions for the auxiliary structures:

1. Refer to Codes, Standards, and Criteria, Appendix E, Item 14 .

2. Refer to Interfaces, Appendix C, Item 17.

3. Refer to Interfaces, Appendix C, Item 5. 
BNWL -500

Volume 22

DDCN-1 1. Deleted

2. Design loads for the Site Facility structures shall include those found in the Seismic Design Criteria. ${ }^{1}$

3. Each Site Facility structure design shall provide for conventional cranes, hoists, monorails, and other equipment not specifically designed for a particular system.

4. All structures having the potential for handing radioactive materials shall be designed to minimize the spread of contamination. Surfaces of these structures shall be properly prepared to receive special coatings or materials, where warranted. The surface or coating required for decontamination shall be based on the potential hazard. DG-83-AC ${ }^{2}$ shall be used to determine protective coatings and surface preparation requirements.

DDCN - 1

1. Refer to References, Appendix A, I tem 2.

2. Refer to Codes, Standards, and Criteria, Appendix E, I tem 14 . 
BNWL -500

Volume 22

5. Structures or portions of structures exposed to significant quantities of sodium shall be furnished protection. Applicable structures and type protection are the subject of a study. ${ }^{1}$

G. There shall be an exhaust filter facility designed having the following requirements:

1. The filter building shall be designed for remote removal and replacement of filter assemblies. ${ }^{2}$

2. The filter building shall provide for personnel access to the filter banks for replacement of individual filter units.

3. The filter building shall be designed to accommodate the addition of future filter banks without the interruption of filtering exhaust air.

4. The filter building shall be built underground to provide shielding. Shielding shall be adequate for maximum radiation build-up on the filter banks. The shielding requirement shall be determined by a design study. 3

5. The ductwork to and from the filter building shall be underground; arrangement and construction shall be compatible with the requirements of the exhaust air system. ${ }^{2}$

6. There shall be an exhaust fan support structure designed to support the exhaust air equipment.

1. Refer to Support Information Requirements, Appendix B, I tem 4 .

2. Refer to Interfaces, Appendix C, I tem 8.

3. Refer to Support Information Requirements, Appendix B, I tem 5 . 
BNWL - 500

Volume 22

7. The ventilation exhaust stack shall be designed in accordance with the Standard Specification for the Design and Construction of Reinforced Concrete Chimneys (ACI-505). ${ }^{1}$ The height and diameter shall meet the requirements of a study. ${ }^{2}$ The stack shall be designed to optimize the dilution and dispersion of radionuclides to the atmosphere in accordance with AEC Manual 0524, "Standards for Radiation Protection." Isokinetic probes and sample lines shall be located within the stack to take samples of exhaust air. Access shall be provided for the insertion and removal of these probes.

8. Space shall be provided to house the equipment for the inplace testing of filters.

9. A structure shall be provided near the base of the exhaust stack to house the monitoring equipment for determining the concentration of radionuclides in the exhaust gases. This equipment will include electronic gear, vacuum pumps, sample lines, electrical panels, and instrument circuits to carry signals to the control room. ${ }^{3}$

H. A sodium disposal facility shall be designed to house the sodium disposal equipment. ${ }^{4}$ A study will be made to determine the method of sodium disposal; special design requirements may be imposed on the structure at that time.

1. Refer to Codes, Standards, and Criteria, Appendix E, Item 20.

2. Refer to Support Information Requirements, Appendix B, I tem 3 .

3. Refer to Interfaces, Appendix C, Item 20.

4. Refer to Interfaces, Appendix C, Item 17.

5. Refer to BNWL-500, Volume 81, Appendix B, Item 1. 
BNWL -500

Volume 22

I. There shall be a heat dump facility designed to have the following requirements:

1. There shall be support foundations and structures for each of the forced air heat dumps. ${ }^{1}$ Each heat dump shall support forced draft blowers.

2. Each heat dump shall be physically isolated or structural means designed so that a sodium reaction will not propogate to other heat dumps.

3. Within each heat dump, a protection system shall be designed to keep a sodium reaction from spreading from one blower cell to an adjacent blower cell. A system shall be designed to contain the quantity of sodium in one secondary loop in the event of a rupture in that system. The design shall consist of either concrete retaining walls or an earth berm around each blower cell.

4. There shall be a support structure designed to accommodate the emergency heat dump. 2,3

5. There shall be a support structure designed to accommodate the closed loop heat dump. 3,4

DDCN-2 J. The radioactive liquid waste loadout station shall be designed having the following requirements:

DDCN-2 1. Provide for the use of portable storage tanks and/ or casks ${ }^{5}$ to provide necessary storage of radioactive liquid waste in event the waste cannot be economically transferred directly to the 200 Area Waste Disposal Facilities.

1. Refer to Interfaces, Appendix C, Item 13.

2. Refer to Interfaces, Appendix C, Item 14.

3. Refer to Support Information Requirements, Appendix B, I tem 4 .

4. Refer to Interfaces, Appendix C, Item 15.

5. Refer to Interfaces, Appendix C, Item 7 . 
BNWL - 500

Volume 22

2. Provide the loadout station for truck or railroad transfer of liquid waste materials. ${ }^{1}$

K. The sodium receiving station shall be designed for unloading bulk quantities of sodium. ${ }^{2}$ The sodium unloading station shall be located as close to the sodium storage tanks ${ }^{3}$ as practical. The exact method of unloading new sodium has not been determined at this time; special design requirements may be imposed when this has been determined.

L. Structural supports shall be designed for the liquid nitrogen and argon storage and vaporization station. ${ }^{4}$ The liquid gases will be stored in Dewars.

M. The following provisions shall be made for the electrical substations. 5

1. Provide housing and structural support for electrical equipment; this will include normal and emergency power equipment.

2. Electrical power, lighting, instrumentation, and communication services shall be underground from the primary substations throughout the site facility. Where large tunnels are required they shall be designed for proper drainage. The drain design shall consider the type of fire protection provided in the tunnel. Where buried conduit will suffice the individual ducts shall be designed to drain.

1. Refer to Interfaces, Appendix C, Item 7.

2. Refer to Interfaces, Appendix C, Item 17.

3. Refer to Interfaces, Appendix C, Item 5.

4. Refer to Interfaces, Appendix C, Item 18.

5. Refer to Interfaces, Appendix C, Items 1, 2, 3, and 4. 
BNWL -500

N. A steam generating and heating plant shall be designed to house the facility heat and steam generating equipment. A study ${ }^{1}$ will be made to determine the quantity of heat, type of heating media to be used for the FFTF, the fuel storage facility requirements, and a recommended plant layout.

0 . A study ${ }^{2}$ will be made to determine the quantity and source of water, type of treatment plant required, storage requirements, location, and a recommended layout. The water system shall be designed to permit portions of the system to be constructed early for use during construction.

P. The maintenance materials storage building and outside areas shall be designed to contain materials normally not housed within the reactor building complex. A fire resistant building shall be designed to contain paints, solvents, and other flammable materials. An insulated metal structure shall be designed to house equipment, replacement parts, special tools, short term inventory stock, and other items which require enclosing.

A fenced area shall enclose space to store bulky items awaiting installation, such as pipe, plate, valves, and instrument panels. The fence and gate requirements are the same as specified under section 1.2.1.D.2.

A11 gates shall be provided with locks.

1. Refer to Support Information Requirements, Appendix B, I tem 2 .

2. Refer to Support Information Requirements, Appendix B, I tem 1 . 
The maintenance materials storage facility shall be designed for early construction for the receiving and storage of engineered equipment items.

DDCN-3 Q. Radiologica1 Design-Criteria, BNWL-MA-3 and Radiation Protection Procedures, BNWL-MA-6 shall be used as a guide in the design of the shielding and access barriers in order that shielding and/or access barriers will limit radiation exposures to within the requirements of AECM-0524.

DDCN -1 $\underline{1.2 .2}$ Design Safety Criteria ${ }^{1}$

The Design Safety Criteria for the Site Facilities are:

A. A11 buildings and structures will be designed and constructed in accordance with the applicable provisions of the latest editions of the following codes and standards:

(a) Uniform Building Code for the Pacific Coast Building Conf., 1967

(b) Hanford Engineering Standards

(c) Standard Specifications for Design and Construction of Reinforced Concrete Chimneys ACL (505)-54

(d) National Fire Codes

(e) AEC Manua1 - RL Supplement RL-0510-01, Waste Disposal (DSC 1.1$)^{1}$

B. All building layouts where radioactive materials are handled shall be designed to incorporate applicable features necessary to provide contamination control within the limits specified in AECM-0524.

$(\operatorname{DSC} 1.2)^{1}$

C. Roadways and points of egress shall be 1 aid out to facilitate rapid and efficient personnel evacuation, facilitate fire protection and building access in an emergency.

1. Refer to References, Appendix A. Item 4, Section 6 . 
BNWL - 500

Volume 22

DDCN - 1

D. Each site facility structure shall be located and/or designed so that an accident in one structure will not propagate to another structure in a manner which constitutes a potential hazard to the reactor or lead to a subsequent uncontrolled release of radionuclides to the environs. (DSC 1.4) ${ }^{1}$

DDCN-3 E. Personnel radiation protection shall be provided such that personnel radiation exposures are within the limits of AECM- 0524 .

(DSC 1.5$)^{1}$

F. The plant exhaust stack shall be located and sized to minimize hazards to plant personnel and the general public from released radionculides.

(DSC 1.6$)^{1}$

G. Fuel supplies for the Emergency Electrical Power System shall be sited so that fire would not lead to functional loss of emergency electrical power. (DSC 1.7$)^{1}$

H. Site facilities which are essential to prevention and/or mitigation of the effects of radioactivity release accident, potentially damaging to public and plant personnel health and safety, shall be designed with consideration given to additional loads imposed by natural phenomena such as earthquakes, floods, winds, ice, ground water levels and temperature extremes.
(DSC 1.8$)^{1}$

I. All utilities and structures within the scope of the Site Facilities that provide features having a safety function will be designed so that a single failure of any active component will not prevent the performance of that function.

(DSC 1.9$)^{1}$

1. Refer to References, Appendix A, Item 4, Section 6. 
BNIVL -500

Volume 22

\section{SECTION 2.0 PHYSICAL DESCRIPTION OF THE FACILITY}

\subsection{SUMMARY DESCRIPTION}

The site facility is composed of the real estate upon which the Fast Flux Test Facility is built, ground improvements and civil engineering features, plant utilities, and the FFTF outside support facilities necessary to maintain efficient plant operation and availability.

The ground improvements and Civil Engineering features include the site layout, landscaping, drainage, roads, parking areas, and railroads. The location of each support service has taken into account access requirements, potential hazards, and safety requirements. Roads and parking are provided to the reactor building and to other site facilities for receiving and shipping materials and equipment.

The utilities provide the required plant sanitary and process water, sanitary and process sewers, steam, normal and emergency electrical substations, and other utilities as required to support plant operation.

The Site Facility provides complete facilities including all structural features and equipment for the following:

- Exhaust stack

- Maintenance and Materials Storage Warehouse

- Steam Plant (Heating and Cooling Facilities)

- Fuel Storage (for Heating and Emergency Power)

- Water Supply System

- Sewage Disposal Facility

- Miscellaneous Structures

- Gas Bottle Storage Facility 
BNWL - 500

Volume 22

The site facility provides structural features as required for the following:

- Exhaust Filters 1

- Exhaust Fans ${ }^{1}$

- Reactor Heat Dump 2

- Closed Loops Heat Dump 3

- Emergency Core Cooling Heat Dump ${ }^{4}$

- Stack Monitoring Building

- Sodium Disposal Facility ${ }^{5}$

- Radioactive Liquid Waste Facility ${ }^{6}$

- Electrical Substations 7

- Emergency Power Generation Station ${ }^{7}$

- Sodium Receiving Station 5

- Inert Gas Receiving Station 8

2.2 DETAILED DESCRIPTION

2.2.1 Ground Improvements and Civil Engineering Features

The Site Facility is so arranged that it provides the FFTF an attractive, well oriented plant. Appendix G, Drawing SK-3-14395, indicates a tentative layout of the required facilities. The facilities which are a potential hazard are located where they can be isolated or are least likely to interfere with other operations. Attention shall be given to specific requirements of the interfacing systems such as length of lines, elevation of Reactor Heat

\footnotetext{
1 Refer to Interfaces, Appendix C, Item 8 .

2 Refer to Interfaces, Appendix C, Item 13.

3 Refer to Interfaces, Appendix C, Item 15.

4 Refer to Interfaces, Appendix C, Item 14.

5 Refer to Interfaces, Appendix C, Item 17.

6 Refer to Interfaces, Appendix C, I tem 7.

7 Refer to Interfaces, Appendix C, Item 2.

8 Refer to Interfaces, Appendix C, Item 18.
} 
BNWL - 500

Volume 22

Transport System heat dumps to assure natural connection, and separation of emergency generating equipment to provide redundancy. Orientation must be provided for safety, and contamination control, as we11 as fire control, personnel evacuation, and normal utility and site considerations. The evacuation plan will be developed during Preliminary Design.

A standard Hanford security fence is provided around the facility to keep unauthorized personnel from disturbing operations. The fence is arranged so that free access is allowed to the main entrance. Personnel control into the main reactor complex is accomplished by the structures Facility. ${ }^{l}$ The fence has a minimum number of gates. The number and location of gates shall be integrated with the plant evacuation plan. Each gate has a lock which is keyed into the Hanford Security System. Other fences and barricades are provided as necessary for personnel safety and protection of property.

These will include radiation barricades and signs near the filter building, radioactive liquid waste facility, waste pond(s) and the sodium disposal facility; fences around the electrical substation transformers; and a fence enclosing the maintenance and materials storage area.

Twenty foot wide asphaltic surfaced roads provide access to the site and reactor building complex from the Hanford Plant Highway System. The perimeter road is also 20 feet wide to permit large trucks and maintenance equipment freedom of movement without interfering with other vehicular movement. The perimeter road also allows quick access for fire protection equipment. Service drives

1 Refer to Interfaces, Appendix C, Item 5. 
B.VWL -500

Volume 22

shall be 14 feet wide where they dead end. Standard safety features are provided throughout the road system. These include centerline stripes, road signs, and safety devices at power 1 ine crossings etc.

A railroad spur connects the FFTF site to the Hanford Plant Railroad System. The spur extends into the reactor building receiving and shipping area. Car spotting and unloading areas are provided for the following:

- Sodium Receiving Area

- Gas Storage Area

- Radioactive Liquid Waste Facility

- Maintenance Materials Unloading Area.

Safety features provided for the railroad spur include the proper clearances between buildings and overhead power lines, signs and signals, as well as standard construction features. The railroads spur into the plant is arranged to service as many facilities as practical without interfering with other systems. Consideration has been given to using the majority of the trackage for early construction purposes. Many early delivery items, construction materials, and equipment can benefit from this service.

The site is so oriented that sufficient space is allowed for future construction or additions to the FFTF. Additions to the FFTF which may be provided for are: FFTF Engineering Operations Building, The Inert Gas Cell Examination Facility, Radioactive Maintenance Facility, and the Reactor Heat Transport Building. The facilities inside the Structures Facility may not be sufficient for future needs. Therefore, provisions are made for new and future programs. 
BNWL - 500

Volume 22

Some of the Site Facility structures may also need to be increased due to new processes or due to requirements which exceed present capabilities. The filter building must have the capability for continuous operation while the plant is operating. It also must have the capability of being expanded while the filtering of air is being accomplished. Sufficient space and planning will allow this capability. There is sufficient space near the electrical substations to allow expansion. The direction which the facility will expand is noted in order that it can be essentially free of interferences.

The heat dump area allows for the expansion of the heat dissipating units. Provisions are made to confine the spread of liquid sodium in event of a rupture in the heat dump facility. Earth berms or basins are provided to contain the amount of sodium within one heat transport system secondary loop thus keeping any reactions from spreading from one unit to another. Structural concrete fire walls are constructed between heat dumps so that large sodium reactions will not propagate to an adjacent heat dump. The location of the Site Facility structures, roads, piping, utilities etc. has been considered in case it may be necessary to change out the FTR reactor vessel internals. Space has been left void, as nearly as possible, so that rigging and other structural considerations will be allowed with the least amount of effort and cost. This consideration is also beneficial for installation of the initial FTR internals if delivery and construction conflict.

Paved parking areas are provided for the employees and visitors. A paved loading and unloading area is provided for buses near the main building entrance. The main 
employee parking lot is designed to handle up to 100 vehicles since it is expected that the majority of employees will be traveling to work via private vehicle. This area has the possibility to be enlarged to twice its capacity should future needs warrant expansion. One-way traffic in and one-way traffic out of the parking lot is planned to avoid confusion during rush hours and to provide safety for personnel walking from the vehicles to the plant. Signs and painted markers indicate the traffic pattern and the individual parking stalls. Precast concrete bumper logs are provided for durability and to allow foot traffic between parked vehicles.

The visitors' parking area is separate from the employees parking. It will accommodate up to 20 vehicles. Although it is expected that there will be up to 100 visitors at one time, it is assumed that the majority of these will be coming by bus to the site.

The bus unloading area is located so that it can come into the area with the normal flow of traffic, unload personnel, and continue without personnel having to cross a roadway. sufficient space is provided to allow several buses to park during loading.

A series of plans will be developed integrating the permament site structures and utilities, the temporary construction needs, future facility requirements, and the site development work. These plans show as a minimum all buried and overhead utilities, all permanent structures, future construction areas, temporary construction requirements, and the ground improvements and Civil Engineering features. The general area has sufficient drainage to carry surface water away from the various structures and roads to natural drainage. The entire area, except for the areas to be 
BNWL -500

Volume 22

landscaped, has been sterilized by a chemical means or by placing a 4 inch leveling course of coarse gravel to discourage weeds and wind erosion.

The landscaping gives the entrance and access to the plant an appealing appearance. The main access road from the Hanford Highway to the main entrance will have trees and shrubs planted along either side of the road. Grass, trees, and shrubs with lighting effects for evenings is planned for the immediate area around the main entrance. An automatic sprinkler system provides regular watering service.

\section{$\underline{2.2 .2 \text { Utility Services }}$}

The plant utilities include the sanitary and process water systems, sanitary sewer system, process sewer system, radioactive waste disposal lines, and the steam generating and distribution system.

A. Sanitary and process water--Water for process, fire protection and potable needs is supplied from a common source. A study ${ }^{1}$ is being made to determine the source, reliability, quality, and quantity of water required for FFTF. The main supply line loops the reactor building complex for pressure distribution and fire protection. Fire hydrants are installed at appropriate locations for complete coverage. The type of fire protection is provided by "Plant Fire Protection System."

The sanitary water main supplies water to all site facilities. Sanitary water is used for both potable and process water. The Service Piping System receives water from the sanitary water loop, and stores it in a covered reservoir. Process water is made up from the sanitary

1 Refer to Support Information Requirements, Appendix B, I tem 1 . 
$\mathrm{BNWL}-500$

Volume 22

water, however, it is isolated by an air gap to make it impossible to get backflow into the sanitary water system. The process water is then pumped from the covered reservoir to the process water system which services all FFTF process water requirements.

B. Sanitary Sewer--The sanitary sewer system collects and disposes of the sanitary wastes from all FFTF facilities. The sewer lines connect to these facilities and extend to the sewage disposal facility. The disposal system is designed to accommodate future employees as we 11 as the planned startup and visiting personnel.

C. Process Sewer--The FFTF process sewer system extends from the interface with the Service Piping system ${ }^{1}$ at the reactor building to the point of discharge at the ponds. A schematic diagram of the process sewer is shown on Drawing SK-3-14340, Appendix G. The process sewer system handles only nonradioactive liquid streams from the reactor building, site facility structures, and future facilities. The process sewer system includes piping valves, manholes, diversion structures, monitoring equipment, and disposal ponds.

A11 process wastes are routinely collected and discharged to one of two ponds via a monitoring station and diversion structures. If the activity level exceeds preset limits for disposal to ground $\left(<5 \times 10^{-5}\right.$ $\mu \mathrm{Ci} / \mathrm{cm}^{3}$ ) an alarm is sounded and the streams are shut off until the source is located and corrective measures taken. All process waste streams connected to the system must be capable of being shut off without causing a reactor shutdown.

1 Refer to Interfaces, Appendix C, Item 6 . 
BNWL -500

Volume 22

Two ponds are provided for the system. Each pond is sized to accommodate 100 percent flow. The diversion structure is designed to divert the flow to either of the two ponds. One pond can be taken out of service for maintenance work such as cleaning and scarifying. The ponds are bounded by earth berms and provided with Hanford Standard Barricades, AC-5-2.1

The ponds are sized based on soil percolation rates to be determined by field tests during Preliminary Design. The ponds are located adjacent to the site outside the perimeter road.

D. Radioactive Waste Lines--Radioactive waste lines are provided to transfer liquid wastes from the reactor service building and containment vesse ${ }^{2}$ to the radioactive liquid waste facility. ${ }^{2}$ These lines are located in concrete trenches with removable covers and are buried to depths necessary to satisfy the requirements of AECM-0524 $4^{3}$ for the highest level of activity that the line will carry.

E. Steam Lines--Steam lines are required to service the FFTF. Steam supply and condensate return lines are provided to the "Service Piping System" for cleaning and processes uses within the reactor service building. These lines are buried, where practical, and shall run from the heating source to the various site facilities

1 Refer to Codes, Standards and Criteria, Appendix E, Item 11.

2 Refer to Interfaces, Appendix C, Items 5 and 10.

3 Refer to Codes, Standards and Criteria, Appendix E, Items 10,21 and 24 . 
B.NiL -500

Volume 22

requiring heat and steam. Drawing $5 k-3-14540$ in Appendix $G$ shows the steam lines required to service the FFTF facilities.

F. Other Miscellaneous Utilities--The remaining utility service lines are described by the individual system responsible for supply and use. The site Facility will route these utilities in the most direct and practical means available. The Site Facility will provide the encasements which require specific structural design or which are required for road, and railroad crossings, or where interferences between individual service 1 ines require special designs. The services which presently fall into this category are as follows:

- Electrical Power

- Outside Lighting

- Communications

- Inert Gases

- Sodium Receiving

- Sodium Disposal

- Oil (or gas) supply

Lines carrying radioactivity are isolated from other lines in order that future installations or maintenance will not be hindered.

\subsubsection{Auxiliary Structures}

Each of the Site Facility structures has been designed to provide personnel with sufficient means to keep radiation dose rates within acceptable limits. This is accomplished by: 
BNWL- 500

Volume 22

- Providing access and radiation shielding where radioactive materials are stored or collected. - Installing barricades and warning signs where dose rates may be above allowable standards.

- Provide drainage or enclosures where equipment rupture would release large amounts of liquid or airborne wastes.

In addition, the structures design provides for the ease of decontamination of surfaces if required. This includes the proper surface preparation to receive paint or chemical resistant coating, steel liners, or other embedded items to protect equipment or building surfaces. Each area within all structures has been reviewed to determine the surface finish requirements. Some areas require only hardners or paints, while other areas require chemical resistent coatings or stainless steel liners.

Each site facility structure was reviewed before final location to assure that an accident in one structure will not propagate to another structure or interfere with operations or safety shutdown of the reactor. The stack, filter building, steam plant, and heat dumps were located where the prevailing winds will normally carry effluents away from the facility. Those structures whose possible failure would interfere with other vital structures are physically isolated so that an unsafe condition does not exist. As an example, the stack is isolated so that the reactor containment or emergency electrical substations would not be damaged if the stack should fail at the base. 
BNWL - 500

Volume 22

Each structural design provides the nonprocess equipment to handle the various needs in the individual structures or facility. This includes the conventional cranes, hoists, monorails, and other equipment not specifically designed for a particular system. The equipment 1 ist will be developed during Preliminary Design.

A. Filter Building--The filter building houses a11 the valves, filters, and equipment necessary to filter the air from the Heating and Ventilation System before releasing it into the atmosphere. A study ${ }^{1}$ will be made to determine the exact requirements of the filters and the building. The filter vault will be provided with a drain to the Radioactive Waste System. ${ }^{2}$ The building is designed for:

1. Remote removal and replacement of filter bank assemblies. These assemblies will have many individual filters arranged in a removable frame.

2. Personnel access for inspection or replacement of the individual filters.

The filter building is built underground accommodating filter removal and taking advantage of the earth for shielding. An earth berm provides sufficient shielding for personnel and is constructed around the perimeter of the filter building.

The filter building design has made provisions to allow future construction of a filter building without interruption of the present filtering process. This is accomplished by having easily removable openings for future duct connections.

1 Refer to Interfaces, Appendix C, Item 8.

2 Refer to Interfaces, Appendix C, Item 7 . 
BNWL -500

Volume 22

B. Ductwork--The ductwork to and from the filter building is located underground. This provides sufficient shielding and allows freedom of movement above the ground surface. The section of the exhaust duct from the filter building to the ventilation stack supports the exhaust fans and equipment. The inside of the duct has been treated to keep dust to a minimum so as not to fill the filters. Exterior loads will determine the structural design of ductwork and will be determined during Preliminary Design. Access into the ducts is through the Reactor building, Filter building and at the base of the stack.

C. Stack--The ventilation exhaust stack is a reinforced concrete structure ${ }^{1}$ extending approximately 200 feet $^{2}$ above grade. The stack has penetrations for the isokinetic probe, the instrumentation lines, personnel access, and for the duct breach. The isokinetic probe is removable. The probe is located about midheight of the stack and accessible to personnel from the exterior of the stack via ladder rungs. Access into the stack is through a standard manhole located at grade. Operating parameters are determined by the Heating and Ventilation system. 3

D. Stack Monitoring Building--This building houses the radiation monitoring equipment. 4 It is located at or near the base of the stack. It is sized to house a particulate and a gas monitor, electronic equipment, vacuum pump, recorders, and other support equipment. It has a concrete foundation and insulated metal siding and roof.

1 Refer to Codes, Standard and Criteria, Appendix E, Item 20.

2 Refer to Support Information Requirements, Appendix B, Item 3.

3 Refer to Interfaces, Appendix C, Item 8.

4 Refer to Interfaces, Appendix C, Item 20 
BNWL - 500

E. Sodium Disposal Building--The sodium disposal building requirements are dependent upon a design study. 1

F. Radioactive Liquid Waste Facility--Radioactive wastes are collected from various systems within the reactor building and the sodium disposal facility. The liquid wastes are piped to the waste facility. The radioactive liquid waste facility is sized to accommodate the tanks, equipment, and piping necessary to process radioactive wastes.

The Radioactive Liquid Waste Facility, as shown on SK-3-14114, 3 , consists of an above grade building $66 \mathrm{ft}$ wide by $100 \mathrm{ft}$ long by $22 \mathrm{ft}$ high and a below grade tank vault $30 \mathrm{ft}$ wide by $66 \mathrm{ft}$ long by $18 \mathrm{ft}$ deep. The above grade structure houses the control room; sampling and monitoring room; change room equipped with shower, sink, water heater, and toilet; neutralizing equipment room; railroad tank car loadout station; and shielded cask loadout station. It will have reinforced concrete foundations to a depth below frost; concrete floors on compacted subgrade; structural steel framing with insulated vermiculite and built-up asphalt roof, exterior walls to be insulated metal siding, access doors for railroad and truck to be mechanically operated, a 35 ton overhead bridge crane, and standard reinforced concrete shielding walls.

The below grade tank vault is reinforced concrete with separate shielded cells, each $14 \mathrm{ft}$ wide by $16 \mathrm{ft}$ long by

1 Refer to Interfaces, Appendix C, Item 17; and BNWL-500, Volume 81, Appendix B, Item 1.

2 Refer to Interfaces, Appendix C, Item 7.

3 Refer to Drawings, Appendix G. 
BNWL -500

Volume 22

$18 \mathrm{ft}$ deep for the four storage tanks and separate inlet and outlet shielded pipe chases. Removable concrete cover blocks in the top slab permit access to cell and pipe chases. Personnel access ports are also provided for routine maintenance, inspection, and equipment calibration. Shielding is designed to limit personnel dosage in accordance with AECM-0524 and BNWL-MA-6. ${ }^{1}$

Support services for the facility shall include:

- Electrical Power - Normal electrical power is provided by the Building Electrical Power System. ${ }^{2}$

- Lighting - General illumination is provided by the Lighting system. ${ }^{3}$

- Communications - Communications equipment such as telephones, intercoms, and public address shall be provided by the Communications systems. ${ }^{4}$

- Ventilation - Ventilation is provided by the Heating and Ventilation System. 5

- Service Piping - Process water, sanitary water, safety showers, drinking fountain, shower and toilet facilities, sanitary sewer, instrument air, and steam are provided by the Service Piping System ${ }^{6}$ as indicated on Drawings SK-3-14114, SK-3-14116, and SK-3-14121.7

- Underground Piping - Underground service piping as shown on SK-3-14113 ${ }^{7}$ are provided by the Site Facilities. Radioactive liquid waste piping is enclosed in an encasement which slopes to a sump at the Radioactive Liquid Waste Facility.

1 Refer to Codes, Standards and Criteria, Appendix E, Items 21 and 24.

2 Refer to Interfaces, Appendix C, Item 2.

3 Refer to Interfaces, Appendix C, Item 4.

4 Refer to Interfaces, Appendix C, Item 3.

5 Refer to Interfaces, Appendix C, Item 8.

6 Refer to Interfaces, Appendix C, Item 6.

7 Refer to Drawings, Appendix G. 
BNWL -500

Volume 22

- Fire protection for the facility is provided by the Plant Fire Protection System. ${ }^{1}$

G. Electrical Substations--Three substations provide for the FFTF. Substation No. 1 provides a fenced-in area containing the $115 \mathrm{kV}$ primary terminal structure, supporting equipment, transformers, etc. A one story insulated metal building (approximately $60 \mathrm{ft} \times 110 \mathrm{ft}$ ) with concrete basement, houses $13.8 \mathrm{kV}$ and $2.4 \mathrm{kV}$ switchgear. The basement connects to the concrete tunnels which carry power to the low voltage transformers. These tunnels are designed for drainage. Access manholes are provided where required. Fire protection is provided by the "Plant Fire Protection.

Substation No. 2 is located on the opposite side of the reactor sphere from the FFTF Engineering Operations Building. Switchgear is housed in a $50 \mathrm{ft} \times 20 \mathrm{ft}$ insulated metal building. Beneath this structure are concrete tunnels to carry cable trays, (holding electrical cable) to the reactor building complex. Adjacent to this is a fenced-in area about $50 \mathrm{ft} \times 20 \mathrm{ft}$ containing low voltage transformers.

Substation No. 3 is housed in a $40 \mathrm{ft} \times 30 \mathrm{ft}$ insulated metal building located near the FFTF Engineering Operations Building. It contains emergency generators and associated equipment. Adjacent to this building a $30 \mathrm{ft} \times 50 \mathrm{ft}$ fenced-in area is provided for low voltage and emergency transformers. Buried ductwork is provided from the transformer stations to each building. These ducts carry electrical, lighting,

1 Refer to Interfaces, Appendix C, Item 9. 
BNWL - 500

Volume 22

instrument, and communication lines to the facilities requiring such services. Tunnels are sloped to drain and have drainage to dry wells or tie back into the process sewer system.

H. Heating Plant--The heating plant provides steam for heating and process uses. A study ${ }^{1}$ is required to determine the quantity of steam required for heating, quantity of steam for process use, type of fuel, and fuel and storage requirements, and a recommended plant layout.

The Heating Plant Structure is a conventional single story structural steel frame building, with insulated metal siding and concrete slab on grade. The building is sized to accommodate the boilers and associated equipment and necessary facilities for operating personnel. A one-ton electric hoist and monorail system is provided to facilitate handling of chemicals and salts used in boiler house operation. The chemical storage capacity is based approximately 30 day supply requirements. A fire protection sprinkler system for the facility is provided by the Plant Fire protection System. ${ }^{2}$ The facility is provided with a conventional heating and ventilation system, communications, lighting, electrical power, water, and sewage services typical for boiler facilities. Emergency electrical power will be required for oil pumps, condensate pumps, and other equipment necessary to assure continuous operation of the boilers.

The facility will have two automatic oil fired steam boilers, approximately $20,000 \mathrm{lb} / \mathrm{hr}$, operating at a steam pressure

1 Refer to Support Information Requirements, Appendix B, I tem 2 .

2 Refer to Interfaces, Appendix C, Item 9. 
BNWL -500

Volume 22

of 125 psig to furnish the steam requirements for all FFTF uses. Each boiler is capable of approximately two-thirds full load requirements. The system is designed for steam condensate return to the boilers. The boilers are designed and constructed to meet ASME code requirements. The system schematic is shown on Drawing SK-3-14341. ${ }^{1}$ The boilers are "packaged" units complete with required instrumentation and controls. Instrumentation ${ }^{2}$ is provided to indicate boiler operating conditions in the central control room. Two below-grade oil storage tanks for No. 2 fuel oil sized for 30 days supply will be provided.

Nake-up water for the boilers is received from the sanitary water supply and passed through an ion exchanger type water treatment system. A treated storage tank is provided for boiler make-up water. Make-up water is pumped through a deaerator by one of two boiler feed pumps capable of supplying either or both boiler units.

I. Maintenance and Materials Storage Warehouse--An insulated metal building about $36 \mathrm{ft} \times 80 \mathrm{ft}$ provides a storage for maintenance materials not normally housed within the reactor building complex. The structure has concrete floors and footings. It is capable of being locked and has a minimum number of doors. Partitions are provided to separate materials not compatible with one another or require special inventory restrictions. Provisions are made for heating and cooling the building. The building will house such items as equipment, replacement parts, special tools, short term inventory stock, or other items which require enclosing. A small concrete

1 Refer to Drawings, Appendix G.

2 Refer to Interfaces, Appendix C, Item 19. 
BNWL - 500

Volume 22

block structure is provided to house flammable materials. This structure is about $10 \mathrm{ft} \times 12 \mathrm{ft}$ and is isolated from the main building.

A $100 \mathrm{ft} x 80 \mathrm{ft}$ fenced-in area provides space to store bulky items awaiting installation or other short term items which require inventory restrictions. One gate provides vehicular access from this area to the perimeter road.

The maintenance and material storage warehouse will be constructed early for use during construction for storage of engineered equipment and special items. Provision for normal operating inventory of equipment requiring special handling and/or environmental control will be provided in the reactor service building. 1 other warehousing facilities for operating materials and supplies and special equipment are available at the Hanford Plant.

J. Miscellaneous Support Structures--Foundations and other structural support features are provided to other facilities within the Site Facility. These items are concrete footings, slabs, tunnels, structural steel support members, and berms for the following:

- Reactor Heat Dump

- Emergency Heat Dump

- Closed Loop Heat Dump

- Sodium Receiving Station

- Liquid Gas Receiving and Storage Station Fuel Supplies for Heating Plant and Emergency Electrical Power Generation

1 Refer to Interfaces, Appendix C, Item 5. 
BNWL -500

Volume 22

\section{$\underline{\text { SECTION } 3.0 \quad \text { SAFETY CONSIDERATIONS }}$}

3.1 HAZARDS

There are numerous hazards that exist near a nuclear facility which handles radioactive materials. Potential hazards fall

in the following general categories:

- Accidental release of radioactive materials

- Damage to critical structures or services for plant operation

- Radiation exposure to personnel

- Potential fire hazard of combustible materials

- Potential fire hazard of sodium reactions.

\subsection{PRECAUT IONS}

To cope with the potential hazards mentioned above, the following precautions are taken:

- The exhaust stack is sized and located to minimize the hazard associated with the release of radionuclides.

- The stack, radioactive waste facility, and filter building are located away from the FFTF Engineering Operations Building, and escape routes, taking into consideration the most probable path of windborne release of radionuclides.

- The site facility is designed so that there is a minimum hazard or damage to vital services. Each facility is located so that an accident in one facility will have a minimum effect on adjacent facilities.

- Radioactive materials are handled in shielded enclosures that can be isolated in case of spillage.

- The road system is oriented for rapid personnel evacuation and so that hazardous locations can be reached from more than one direction by fire protection equipment. 1

1 Refer to Interfaces, Appendix C, Item 9. 
BNWL -500

Volume 22

- Air blast heat exchangers are spaced so that the facility can continue to operate in the event of a sodium reaction.

- Flammable liquids are contained in underground vaults or a berm is constructed to contain the fluids.

- Facilities handling radioactive materials are designed to prevent the release of radioactivity. 
BNWL -500

Volume 22

SECTION 4.0 PRINCIPLES OF OPERATION

The FFTF Site Facility has many operating facilities within its boundaries. The description of the operation is not within the scope of this concept, but rather, within the principles of operation of the various concept design descriptions of the systems involved. 
BNWL - 500

Volume 22

\section{SECTION 5.0 MAINTENANCE PRINCIPLES}

5.1 GENERAL MAINTENANCE

The design philosophy for general maintenance of this facility is similar to other nuclear plants, and will include such items as:

- Periodic checks of personnel and equipment safety devices. This includes such items as clean decontamination stations, repair of protective coatings and linings, repair of remote handling equipment for replacement of filters in the heating and ventilating systems, etc.

- Repair of failed equipment such as cranes and hoists, access doors, hatches, etc.

5.2 PREVENTIVE MAINTENANCE

The design philosophy for preventive maintenance closely follows the philosophy for general maintenance, and will include such items as:

- Periodic checks of personnel and equipment safety devices. This includes such items as protective coatings of floors, walls and ceilings, linings, and drainage systems.

- General periodic checks of equipment. Such items include airlocks, cranes, waste handling devices, etc.

Maintenance is performed to assure that protective coatings are in good shape and that linings are not leaking. 
APPENDIX A

REFERENCES 
BNWL -500

Volume 22

\section{APPENDIX A}

\section{REFERENCES}

1. C. C. Stee1e. FFTF Overall Conceptual Systems Design Description, BNWL-500, Vol. 1., Battelle-Northwest, Richland, Washington, July 7, 1967.

2. E. R. Rybarski and J. R. Samuel. Unpublished Data. FFTF Seismic Design Criteria, A-0078, BattelleNorthwest, Richland, Washington. (Preliminary Issue)

3. F. H. Shade1. Fast Flux Test Facility Site Evaluation, BNWL-906. Battelle-Northwest, Richland, Washington, October 1968 .

DDCN-1 4. Design Safety Criteria for the Fast Flux Test Facility, BNWL-823, Battelle-Northwest, Richland, Washington, June 17,1968 . 
APPENDIX B

SUPPORT INFORMATION REQUIREMENTS 
APPENDIX B

SUPPORT INFORMATION REQUIREMENTS

\begin{tabular}{|c|c|c|c|c|}
\hline Item & Information Required & Type of Effort & Source & When Required \\
\hline 1 & $\begin{array}{l}\text { Facility Water } \\
\text { Requirements }\end{array}$ & Design Study & $A-E$ & Preliminary Design \\
\hline 2 & Facility Heat Source & $\begin{array}{l}\text { Engineering } \\
\text { Study }\end{array}$ & $A-E$ & Preliminary Design \\
\hline 3 & $\begin{array}{l}\text { Ventilation Exhaust } \\
\text { Stack Study }\end{array}$ & $\begin{array}{l}\text { Engineering } \\
\text { Study }\end{array}$ & PNL / SU - 2 & Start Final Design \\
\hline 4 & $\begin{array}{l}\text { Structural Requirements } \\
\text { for the FFTF Heat Dumps }\end{array}$ & Design Study & $A-E$ & $\begin{array}{l}\text { Preliminary Design } \\
\text { early }\end{array}$ \\
\hline 5 & $\begin{array}{l}\text { Filter Building } \\
\text { Shielding }\end{array}$ & Design Study & PNL/DSA - 4 & Preliminary Design \\
\hline 6 & $\begin{array}{l}\text { Individual System Reli- } \\
\text { ability and Availability } \\
\text { Goals }\end{array}$ & $\begin{array}{l}\text { Reliability } \\
\text { Analysis }\end{array}$ & $\mathrm{PNL} / \mathrm{DSA}-1$ & $\begin{array}{l}\text { Preliminary Design } \\
\text { early }\end{array}$ \\
\hline
\end{tabular}


BNWL - 500

Volume 22

1. FACILITY WATER REQUIREMENTS

Objectives

Establish the most reliable and economical source, and the Design Criteria of sanitary and process water supply system for the Fast Flux Test Facility.

Description of Work

Perform a design study based on the selected plant site taking into account the sanitary water requirements and the process water requirements of each facility and system requiring water. This includes water requirements for fire protection.

- Determine maximum water requirements

- Determine emergency water requirements

Based on the FFTF selected site, evaluate the following:

- Availability and feasibility of obtaining water from existing sources

- Modifications required to existing water sources to meet FFTF demands

- New water sources

- Estimated costs of each potential source. Recommended water supply source and system for the FFTF. Design Criteria and requirements for the FFTF water supply system.

\section{FACILITY HEAT SOURCE}

Objective

Determine the source of heat and establish the Design Criteria for the FFTF space and process heating requirements. 
BNWL - 500

Volume 22

Description of Work

This design study shall be based on the recommended FFTF site. The study shall take into account the building heating and process steam requirements of each FFTF Facility and system. Quantity and quality of the steam required of each Facility or System shall be determined. The work includes:

- Determine maximum heating and process steam demand and recommend the plant capacity

- Determine available heat source (new, existing, relocated, reactor heat dump)

- Recommend the heat source

- Provide complete design criteria for the steam generating facility

- Provide a cost analysis of alternate solutions.

\section{VENTILATION EXHAUST STACK STUDY}

Objective

The objective of this study is to determine the most desirable and economic method of discharging the filtered ventilation exhaust air from NPTF and FFTF to meet the radiological requirements of each facility.

Description of Work

Potentially contaminated exhaust air from NPTF and FFTF is collected and filtered in separate exhaust filter facilities. The filtration system is selected to control the release of radionuclides within the limits established in AEC Manual Chapter 0524 and the RL Supplements. The filter choice and recommendations are the subject of a study in the Heating and Ventilation System, CSDD No. 25. 
BNWL - 500

Volume 22

The exhaust air from the filters must be safely discharged to the atmosphere to satisfy radiological requirements for both normal and accident conditions in NPTF and FFTF. Considering the use of a stack to satisfy the above requirements, evaluate the following items:

- The need for separate versus a common exhaust stack for the two facilities (NPTF and FFTF)

- The recommended location for the stack relative to the associated FFTF buildings, ventilation air intakes, meteorological conditions and the surrounding countryside

- The required height for safe discharge of the exhaust air

- The minimum or recommended discharge velocity of the exhaust air

- The most economical arrangement for a stack system to satisfy the above requirements.

4. STRUCTURAL REQUIREMENTS FOR THE FFTF HEAT DUMPS

Objective

Determine the structural design and siting requirements for the FFTF heat dumps for the following:

Reactor Heat Transport System

- Emergency Core Cooling System

- Closed Loop Cooling System.

Description of Work

- Assess hot air release effects on site meteorology and adjacent structures

- Determine safety requirements; i.e., fire protection, personnel access, etc. 
BNWL - 500

Volume 22

- Establish special design requirements; i.e., temperature, pressures, missile protection, vibration, etc.

- Establish structural support requirements for heat dissipating equipment.

\section{FILTER BUILDING SHIELDING}

Objectives

Define the intensity and the spectral and spatial distribution of radiation sources throughout the FFTF, calculate the attenuation characteristics of applicable arrangements of shield materials, audit the design of radiation barriers, and provide technical direction of the off-site experimental work separately funded at AI under LMFBR program.

Description of Work

The purpose of this task is to provide the technical bases for the design of radiation barriers throughout the FFTF. The task includes a number of activities to achieve this goal. Analyses must be made to define the intensity and both the spectral and spatial distribution of all sources of radiation that will be encountered in the operation of the facility. Parametric shielding analyses are to be made for these sources to establish the shielding requirements for each of the systems in which sources are to be located. The results of these parametric studies will be provided to the appropriate systems engineers as a basis for incorporating shielding material into the system design.

6. INDIVIDUAL SYSTEM RELIABILITY AND AVAILABILITY GOALS

Objectives

Determine system reliability and availability requirements. Make study results available so they can be factored into the design effort. 
BNWL - 500

Volume 22

Description of Work

Perform an analysis to predict reliability and availability associated with the Containment System. Reliability analysis will be performed by determining probabilities for system failures. Availability analyses will be performed by determining probability of lost operating time associated with system failures. Results will be factored into design efforts. 
APPENDIX C

INTERFACES 


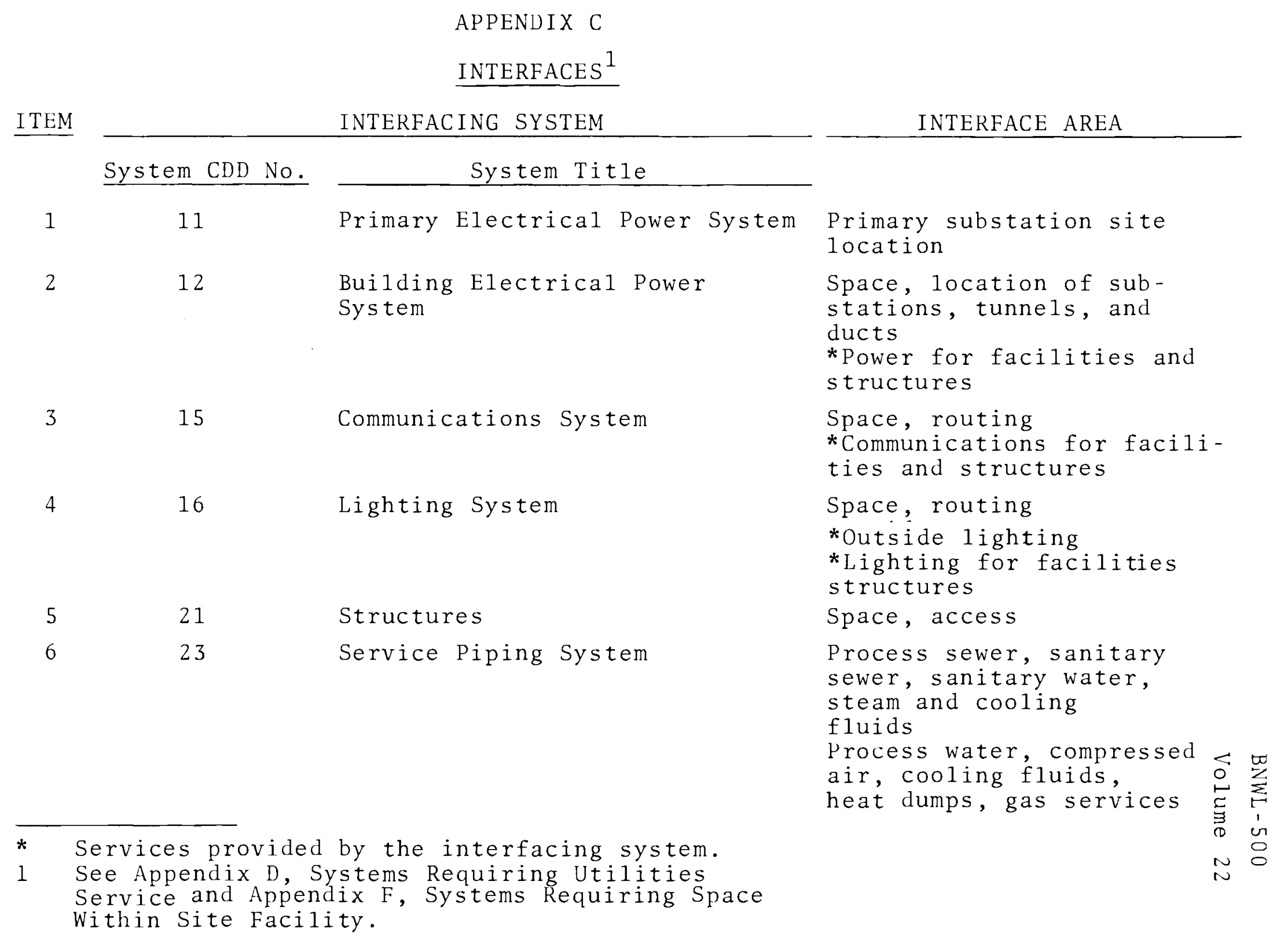




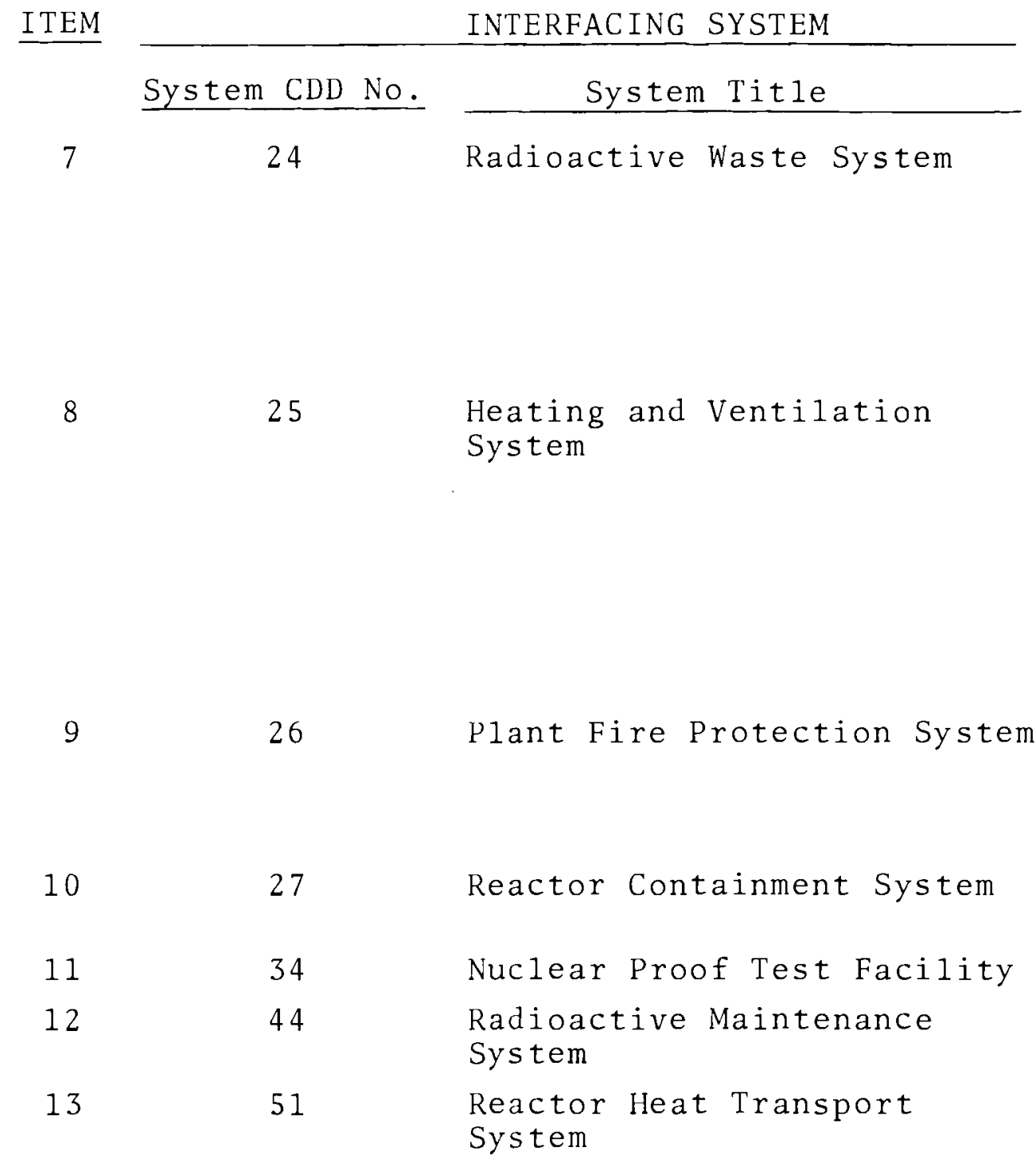


System CDD No.

14

52

61

16

71

Inert Gas Cell Examination

17

81

18

82

93
Closed Loop System Facility

Sodium Receiving and

Processing System

Emergency Core Cooling System

Inert Gas Receiving and Processing System

Plant Instrumentation System
INTERFACE AREA

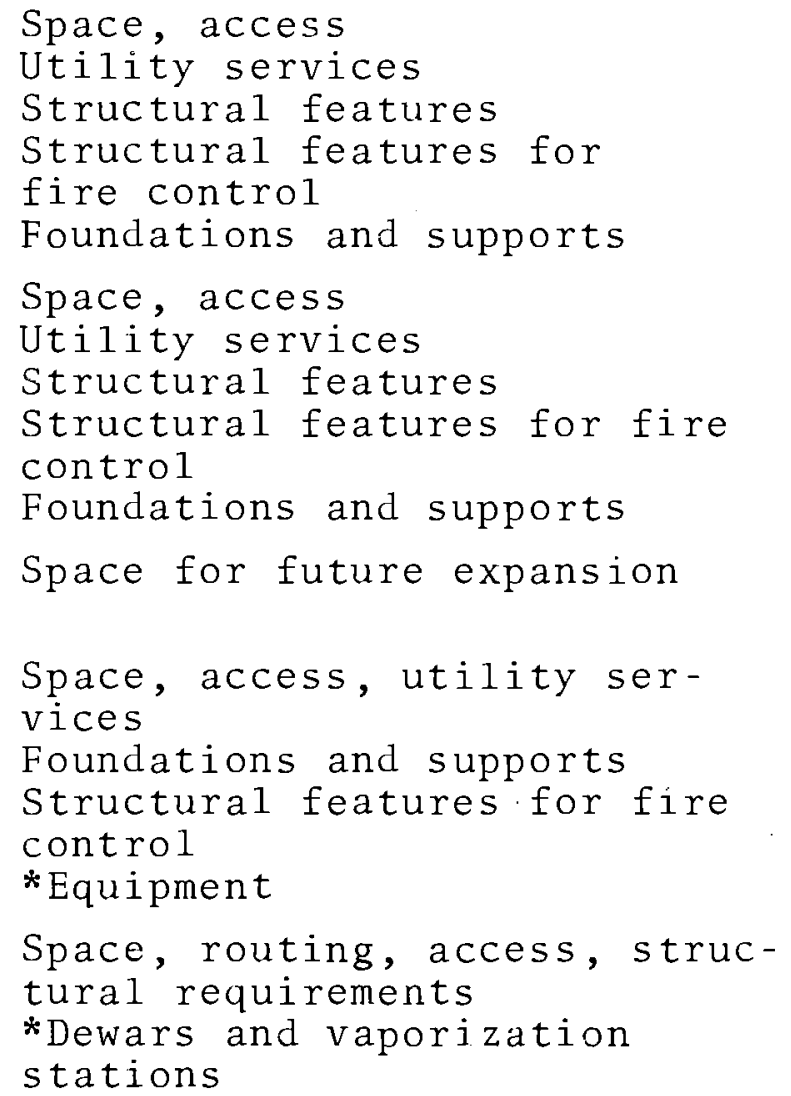

Space, access, routing 
$\underline{\text { ITEM }}$

$\frac{\text { INTERFACING SYSTEM }}{\frac{\text { System CDD No. }}{96}} \frac{\text { System Tit1e }}{\text { Radiation Monitoring System }}$

20
Hanford Plant Transportation
INTERFACE AREA

Access, space, routing * Stack monitoring equipment * Process sewer monitoring equipment

Roads and railroads

* Services provided by the interfacing system. 


\section{APPENDIX D}

SYSTEMS REQUIRING UTILITIES SERVICE 
APPENDIX D

\section{SYSTEMS REQUIRING UTILITIES SERVICE*}

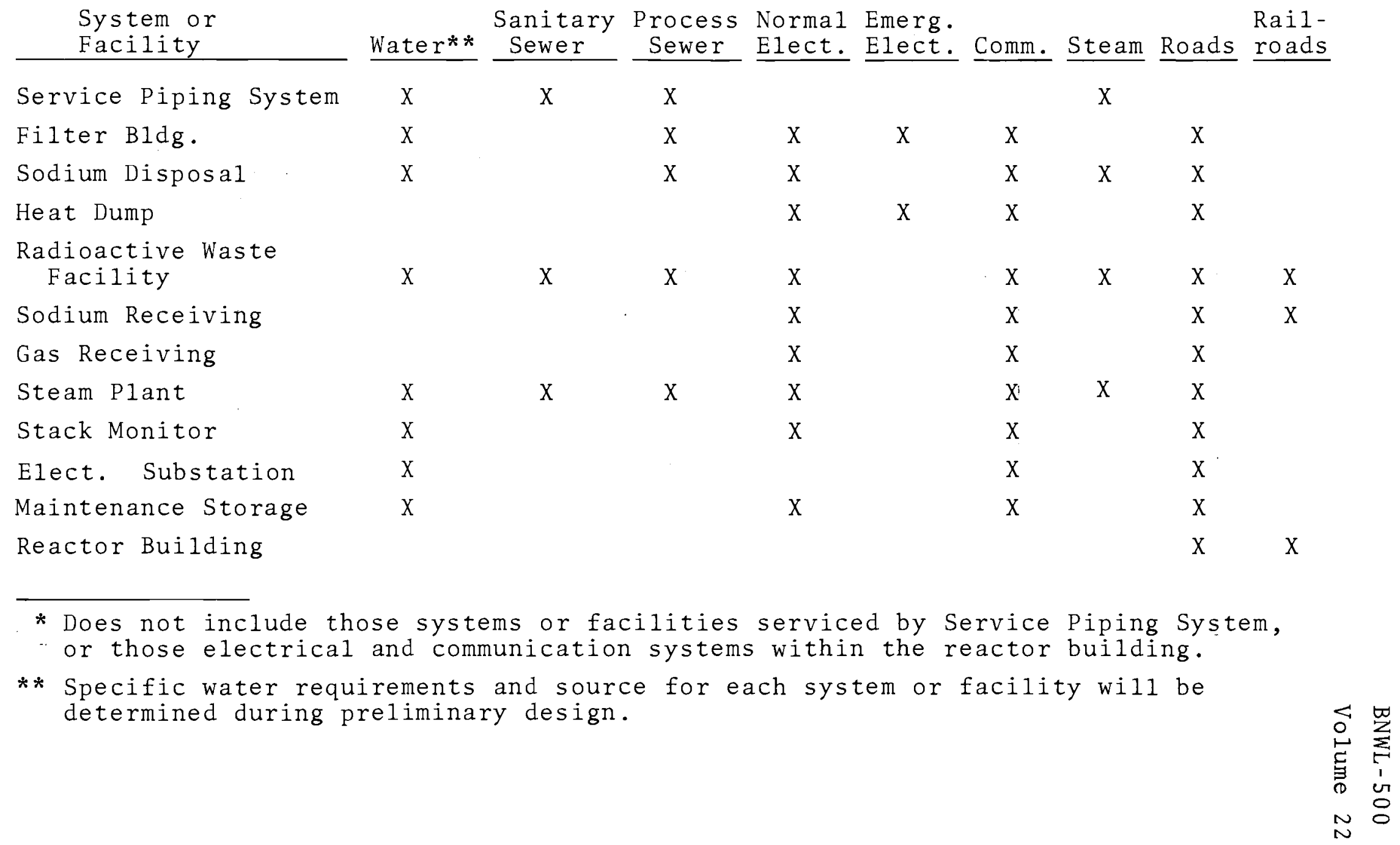


APPENDIX E

FFTF SITE FACILITY

CODES, STANDARDS, AND CRITERIA 
BNWL - 500

Volume 22

DDCN - 1

\author{
APPENDIX E \\ FFTF SITE FACILITY \\ CODES, STANDARDS, AND CRITERIA
}

1. Uniform Building Code, Volumes I and II, International Conference of Building officials, Pasadena, California, 1967, Authorized Edition.

2. Building Code Requirements for Reinforced Concrete (ACI 318-63), American Concrete Institute, Detroit, Michigan, June 1963.

3. Minimum Requirements for Plumbing, National Plumbing Code, (ASA A40.8-1955) American Society of Mechanical Engineers, New York, New York.

4. Pressure Piping Codes, (ASA-B3.1 Series 1966 to 1968), American Standards Association, USA Standards Institute, New York, New York.

5. ASME Boiler and Pressure Vessel Code, Sections I through IX American Society of Mechanical Engineers, 1968, New York, New York.

6. Safety Code for Cranes, Derricks, and Hoists, (ASA-B30.21943, R-1952, ASA-B30.2.0-1967) American Standards Association, USA Standards Institute, New York, New York.

7. National Electrical Code, (ASA-C1-1965), National Fire Protection Association, Boston, Massachusetts, 1965.

8. Handbook of Fundamentals, 1967; Guide and Data BookSystems \& Equipment, 1967; and Guide and Data Book, Applications, $196 \overline{8}$, American Society of Heating, Refrigeration, and Air-Conditioning Engineers, Inc., New York, New York.

9. Manual of Stee1 Construction, American Institute of Steel Construction Inc., New York, New York, 1964, Sixth Edition.

10. Radiological Design Criteria, BNWL-MA-3, Batte1leNorthwest, Richland, Washington, March 1965.

11. Hanford Engineering Standards: HWS-10000 - Architectural and Civil standards. 
BNWL -500

Volume 22

DDCN -1

12. Hanford Engineering Standards: HWS-10001-Mechanical Standards.

13. Hanford Engineering Standards: HWS-10002 - Electrical Standards.

14. Hanford Engineering Standards: HWS-10003 - Guides, Volume 1 .

15. Hanford Engineering Standards: HWS-10003 - Guides, Volume 2 .

16. Hanford Engineering Standards: HWS-10004 - Welding Standards.

17. Hanford Engineering Standards: HWS-10005 - Instrument Standards.

18. Hanford Engineering Standards: HWS-10006 - Standard Design Criteria.

19. Hanford Engineering Standards: HWS-10007-Protective Clothing Standards.

20. Standard Specification for Design and Construction of Reinforced Concrete Chimneys, (ACI-505-54) American Concrete Institute, Detroit, Michigan.

21. Standards for Radiation protection, U. S. Atomic Energy Commission AEC Manual, Volume 0000, Part 0500, Chapter 0524, August 1963, and Standards for Radiation Protection, AEC Manual, RL Supplement, RL 0524-01, February 1964 .

22. Standards for Protection Against Radiation (10 CFR 20), U. S. Atomic Energy Commission, Rules and Regulations Title 10, Atomic Energy, Part 20, April 1966.

23. Sprinklers, Fire Pumps and Water Tanks, Volume 6, National Fire Codes, 1967-1968 National Fire Protection Association, Boston, Massachusetts.

24. Radiation Protection Procedures, BNW-MA-6, BattelleNorthwest, Richland Washington, August 1967.

25. Standard Series Specifications (single Series), American Water Works Association, Inc, New York, New York.

26. General Design Criteria, U. S. Atomic Energy Commission, AEC Manual Volume 6000, Part 6300, Chapter 6301, December 1965 . 
BNWL -500

Volume 22

DDCN -1

27. Prevention, Control and Abatement of Air and Water Po1lution, U. S. Atomic Energy Commission, AEC Manual, Volume 0000 , Part 0500, Chapter 0510, March 7, 1968, and Waste Disposal, AEC Manual, RL Supplement, RL $0510-01$, Ju1y 1967 . 
APPENDIX F

SYSTEMS REQUIRING SPACE WITHIN SITE FACILITY 
BNWL -500

Volume 22

APPENDIX F

SYSTEMS REQUIRING SPACE WITHIN SITE FACILITY*

\begin{tabular}{|c|c|c|}
\hline SYSTEM & TITLE & SPACE REQUIREMENT \\
\hline 11 & Primary Electrical Power & $\begin{array}{l}\text { Substation, future } \\
\text { expansion }\end{array}$ \\
\hline 12 & Building Electrical Power & $\begin{array}{l}\text { Substations, routing, } \\
\text { expansion }\end{array}$ \\
\hline 15 & Communications & Routing \\
\hline 16 & Lighting & $\begin{array}{l}\text { Routing, outside } \\
\text { lighting }\end{array}$ \\
\hline 21 & Structures & Structure \\
\hline 22 & Site Facilities & $\begin{array}{l}\text { Roads, railroads, } \\
\text { water, steam** }\end{array}$ \\
\hline 24 & Radioactive Wastes & Structure,** routing \\
\hline 25 & Heating and Ventilation & Structure, $* *$ routing \\
\hline 26 & Plant Fire Protection & Routing \\
\hline 27 & Reactor Containment & Structure \\
\hline 44 & Radioactive Maintenance & Future expansion \\
\hline 51 & Reactor Heat Transport & Structure, routing \\
\hline 52 & Emergency Core Cooling & Structure, routing \\
\hline 71 & Inert Gas Cell Examination & Future expansion \\
\hline 81 & $\begin{array}{l}\text { Sodium Receiving and } \\
\text { Processing }\end{array}$ & $\begin{array}{l}\text { Unloading station, } \\
\text { routing }\end{array}$ \\
\hline 82 & $\begin{array}{l}\text { Inert Gas Receiving and } \\
\text { Processing }\end{array}$ & Storage, routing \\
\hline 93 & Plant Instrumentation & Routing \\
\hline
\end{tabular}

* Those systems completely housed within another system are not applicable here.

* These structures and utilities are included and described in this CFDD. 
APPENDIX G

DRAWINGS

SK - 3- 14113

SK $-3-14114$

SK- 3- 14116

SK-3-14121

SK $-3-14340$

SK - 3- 14341

SK - 3- 14395 


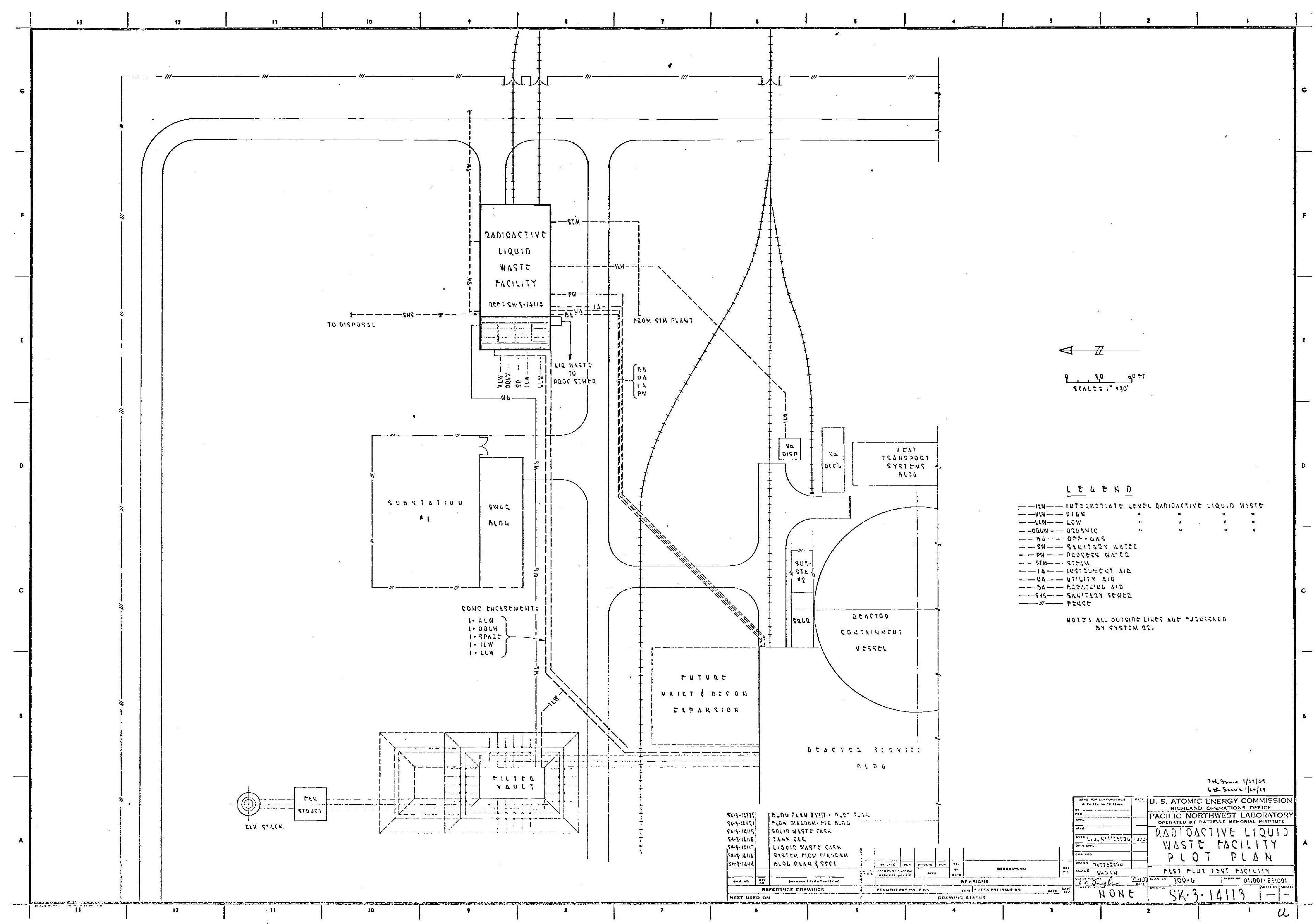




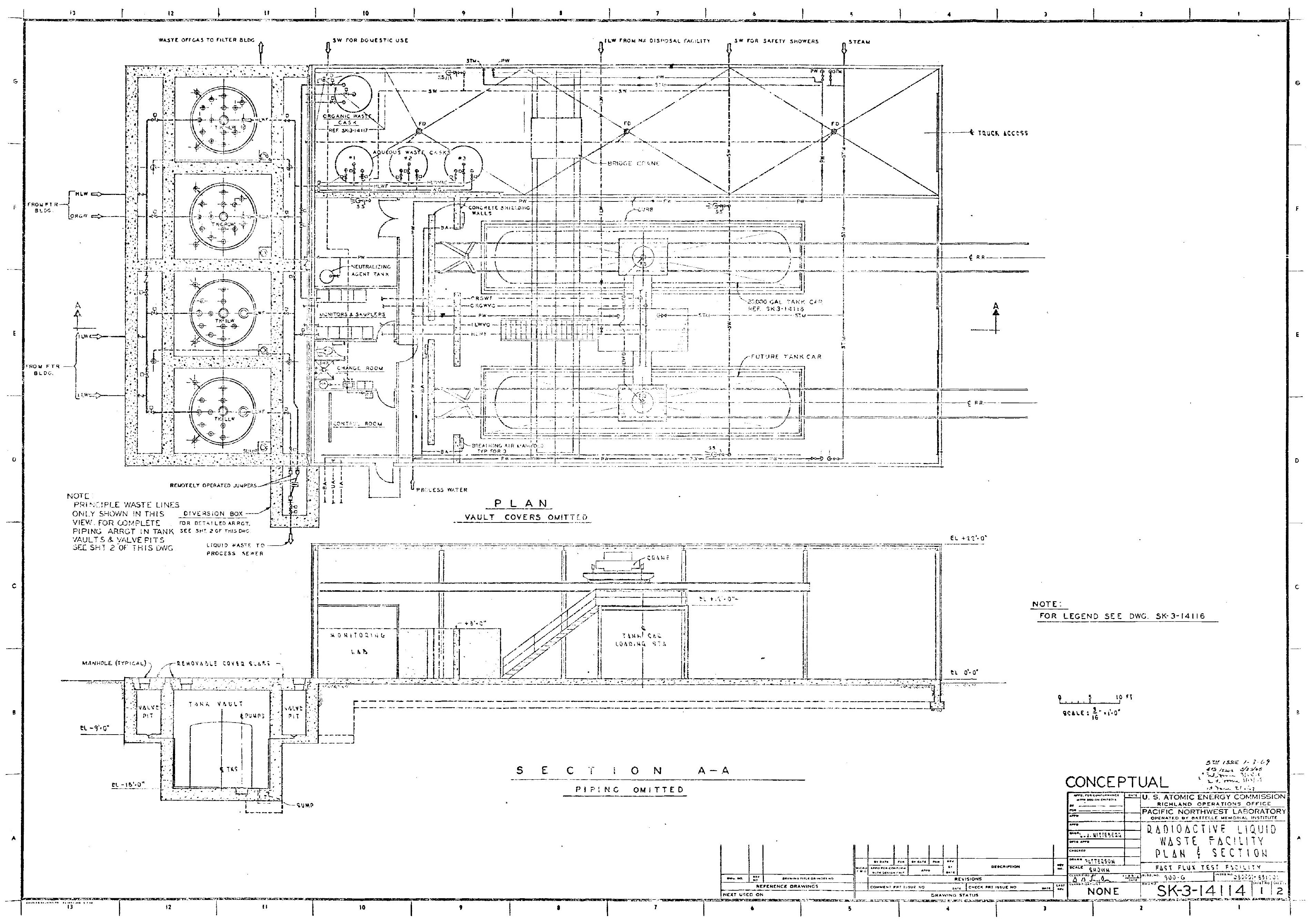




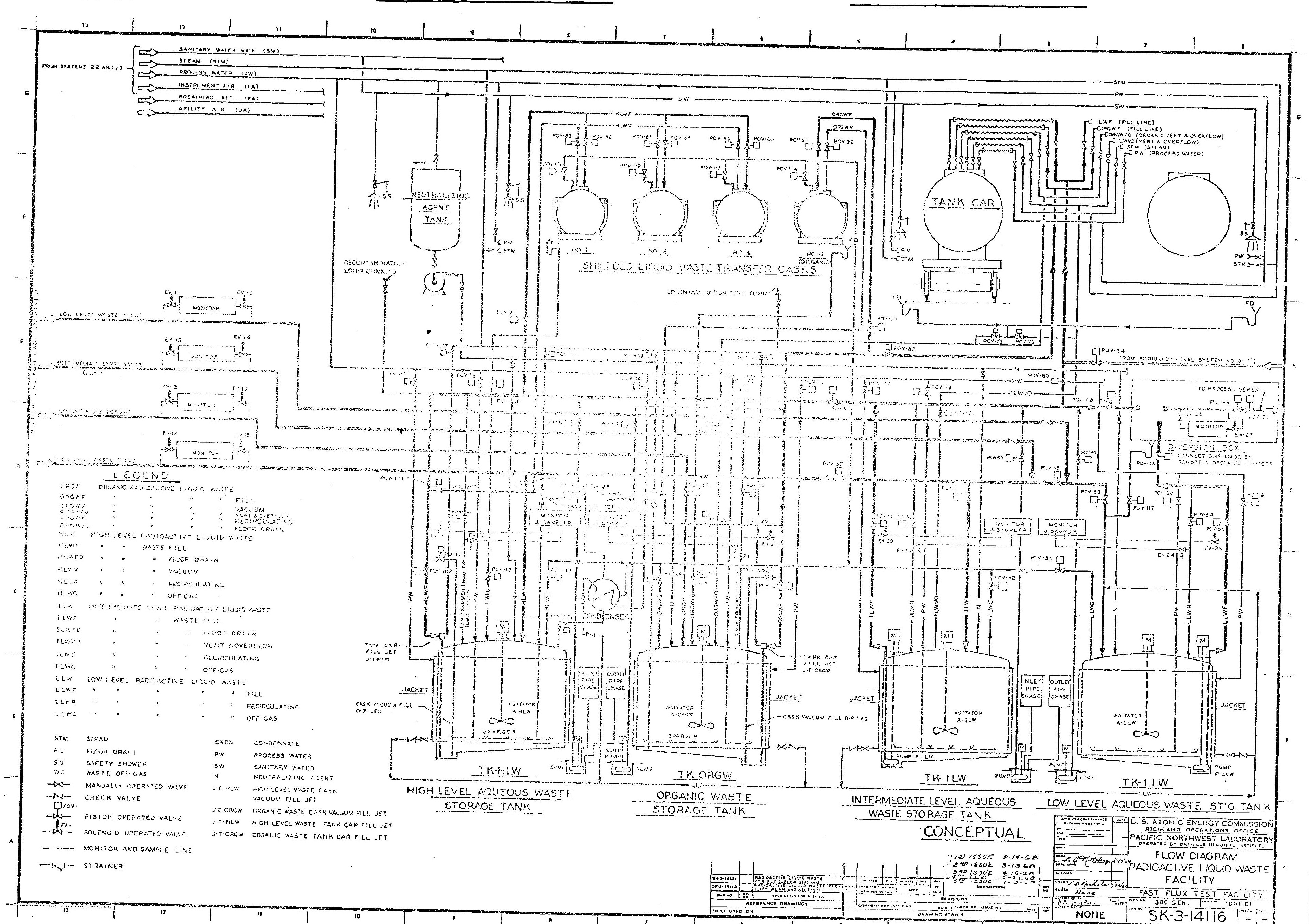




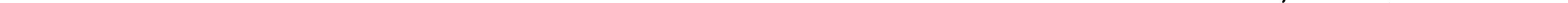




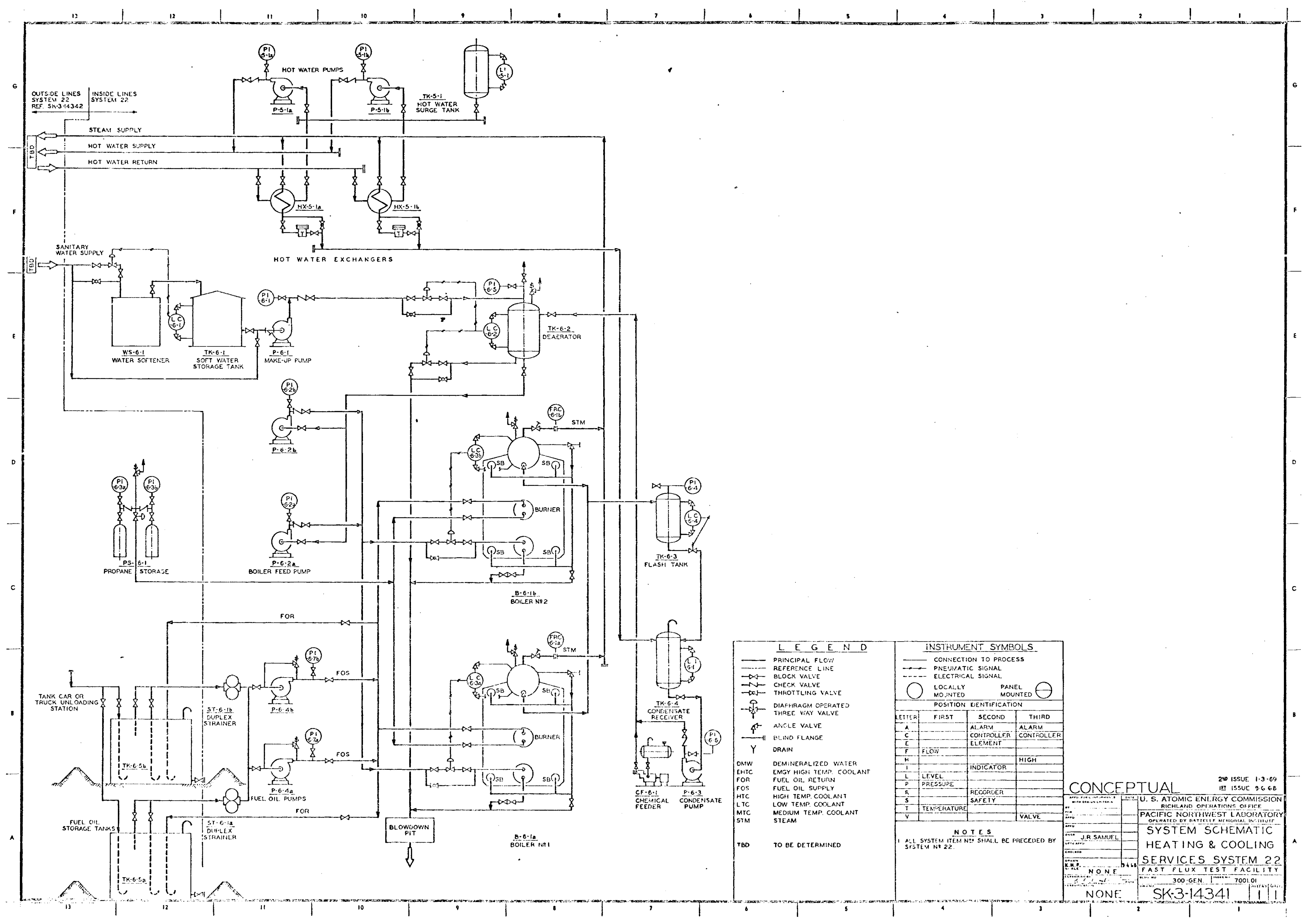




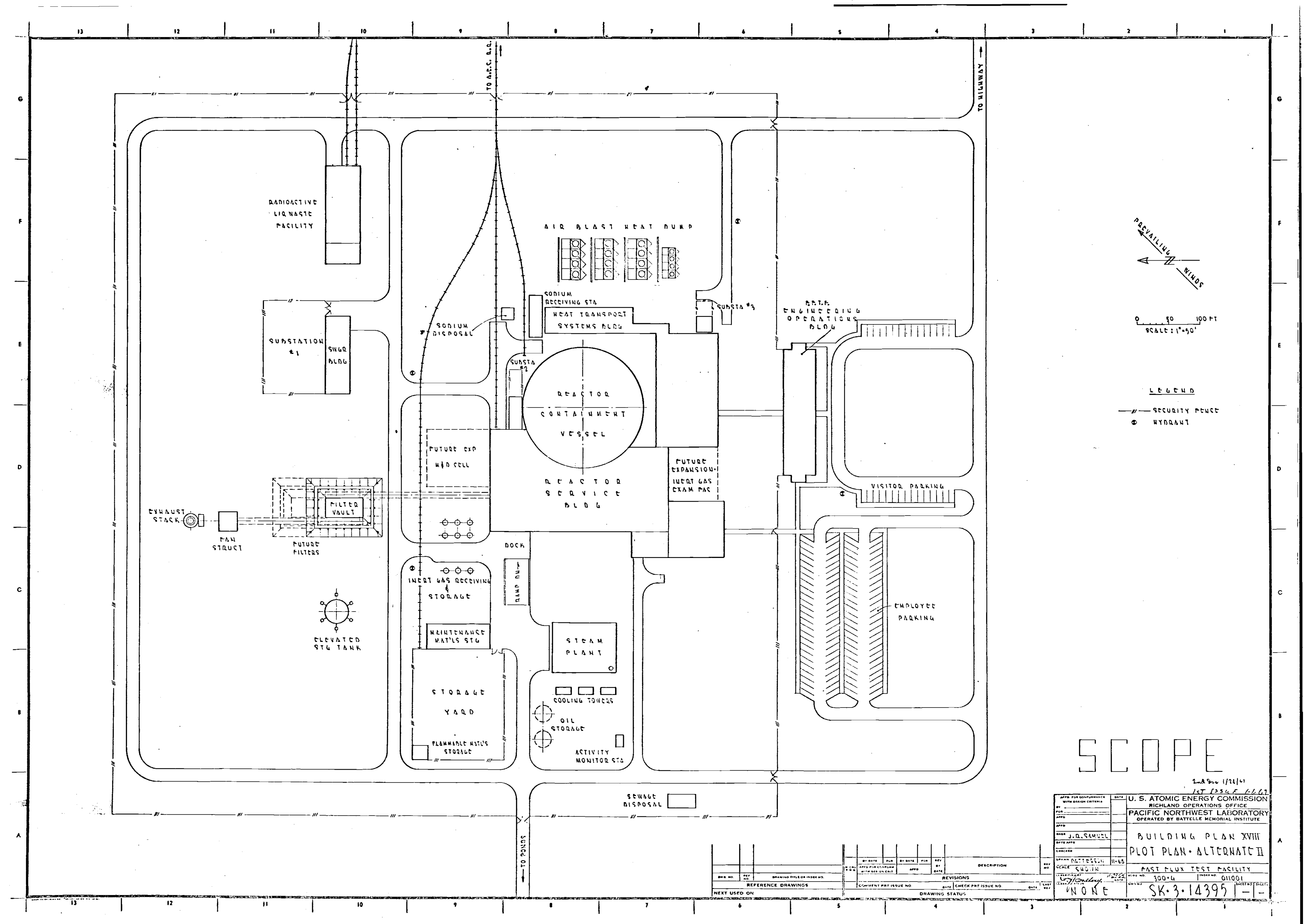




\section{DISTR I BUT ION}

No. of

Copies

U. S. Atomic Energy Commission Division of Reactor Dev \& Tech Washington, D. C. 20545

$M$ Shaw, Director, RDT

Asst Dir for Nuclear Safety

Analysis \& Evaluation Br, RDT:NS

Environmental \& Sanitary Engrg $\mathrm{Br}, \mathrm{RDT}: \mathrm{NS}$

Research \& Development Br, RDT:NS

Asst Dir for Plant Engrg, RDT

Applications \& Facilities Br, RDT:PE Components $\mathrm{Br}$, RDT:PE

Instrumentation \& Control Br, RDT:PE

Liquid Metal Systems Br, RDT:PE

Asst Dir for Program Analysis, RDT

Asst Dir for Project Mgmt, RDT

Liquid Metals Projects Br, RDT:PM

FFTF Project Manager, RDT:PM

Asst Dir for Reactor Engrg

Control Mechanisms Br, RDT:RE

Core Design Br, RDT:RE (2)

Fuel Fabrication Br, RDT:RE

Fuel Handling Br., RDT:RE

Reactor Vesse1s Br, RDT:RE

Asst Dir for Reactor Tech

Coolant Chemistry $\mathrm{Br}$, RDT

Fuel Recycle Br, RDT

Fuels \& Materials Br, RDT:RT

Reactor Physics Br, RDT:RT

Special Technology Br, RDT:RT

Asst Dir for Engrg Standards, RDT

AEC Chicago Patent Group

G. H. Lee, Chief

R. K. Sharp (Richland)

1 ABC Idaho Operations office

Nuclear Technology Division

C. W. Bills, Director

4 AEC Richland Operations office FFTF Program

J. M. Shivley

C. L. Robinson 
DDCN -3

DI STRIBUTION

No. of

Copies

\section{0}

U.S. Atomic Energy Commission
Division of Reactor Dev \& Tech
Washington, D.C. 20545

M. Shaw, Director, RDT

Asst Dir for Nuclear Safety

Analys is \& Evaluation Br, RDT:NS

Environmental \& Sanitary Engrg

$\mathrm{Br}, \mathrm{RDT}: \mathrm{NS}$

Research \& Development $\mathrm{Br}$, RDT:NS

Asst Dir for Plant Engrg, RDT

Applications \& Facilities $\mathrm{Br}, \mathrm{RDT}: \mathrm{PE}$

Components $\mathrm{Br}$, RDT:PE

Instrumentation \& Control $\mathrm{Br}, \mathrm{RDT}: \mathrm{PE}$

Liquid Metal Systems $\mathrm{Br}, \mathrm{RDT}: \mathrm{PE}$

Asst Dir for Program Analys is, RDT

Asst Dir for Project Mgmt, RDT

Liquid Metals Projects $\mathrm{Br}$, RDT:PM

FFTF Project Manager, RDT:PM

Asst Dir for Reactor Engrg

Control Mechanisms Br, RDT:RE

Core Design $\mathrm{Br}, \mathrm{RDT}: \mathrm{RE}$

Fuel Fabrication $\mathrm{Br}$, RDT : RE

Fuel Handling $\mathrm{Br}$., RDT : RE

Reactor Vessels $\mathrm{Br}$, RDT:RE

Asst Dir for Reactor Tech

Coolant Chemistry $\mathrm{Br}$, RDT

Fuel Recycle Br, RDT

Fuels \& Material Br, RDT:RT

Reactor Physics Br, RDT:RT

Special Technology Br, RDT:RT

Asst Dir for Engrg Standards, RDT

2 AEC Chicago Patent Group

G. H. Lee, Chief

R. K. Sharp (Richland)

1 AEC Idaho Operations Office

Nuclear Technology Division

C. W. Bills, Director

4 AEC Richland Operations Office FFTF Program

J. M. Shivley (3)

C. L. Robinson 
DDCN - 3

No. of

Copies

1

AEC San Francisco Operations Office

Director, Reactor Division

4

AEC Site Representatives - PNL

T. A. Nemzek

4

AEC Site Representatives

Argonne National Laboratory

Atomics International

Atomic Power Development Assoc.

General Electric Co.

2 Argonne National Laboratory

R. A. Jaross

LMFBR Program Office

$7 \quad$ Atomics International

D. J. Cockeram (5)

Liquid Metal Information Center

J. J. Droher

3

Battelle Memorial Institute

6 Bechtel Corporation

J. J. Teachnor, Project Administrator, FFTF

M. O. Rothwell (Richland)

5

General Electric Co.

Advanced Products Operation

Karl Cohen (4)

Nuclear Systems Programs

D. H. Ahmann

12 Westinghouse Electric Corp

Atomic Power Division

Advanced Reactor Systems

D. C. Spencer (10)

R. Strzelecki (Richland)

J. S. Theilacker (AI) 
DDCN - 3

No. of

Copies

$72 \quad$ Battelle-Northwest
S. O. Arneson
(2)
W. G. Albert
R. G. Baumgarter
A. L. Bement
R. A. Bennett
J. R. Boldt
C. L. Boyd
D. C. Boyd
W. L. Chase
W. Dalos
R. V. Dulin
L. M. Finch
B. D. Fleming
E. E. Garrett
V. W. Gustafson-FB
J. P. Hale
R. A. Harvey
R. E. Heineman
R. J. Hennig
C. W. Higby
P. L. Hofmann
E. M. Johnston
C. E. Love
J. W. Mitche11
L. J. Nitteberg

C. N. Orsborn

R. E. Peterson

H. C. Riches

W. E. Roake

E. J. Ruane

E. R. Rybarski (2)

F. H. Shade 1

B. O. Shaver

D. E. Simpson

R. J. Squires

C. C. Steele

D. D. Stepnewski

H. W. Stivers

G. H. Strong

C. D. Swanson

W. E. Taylor

N. Vieli

M. A. Voge 1

R. C. Walker

J. H. Westsik

D. Whitford

T. W. Withers

N. G. Wittenbrock-FB

FFTF Files (10)

Tech Files (5)

Technical Publications 
